Research Report No. 19/2010

\title{
The Long Shadow of Colonialism: The Origins of the Doctrine of Emergency in International Human Rights Law
}

John Reynolds

Follow this and additional works at: http:// digitalcommons.osgoode.yorku.ca/clpe

\section{Recommended Citation}

Reynolds, John, "The Long Shadow of Colonialism: The Origins of the Doctrine of Emergency in International Human Rights Law" (2010). Comparative Research in Law \& Political Economy. Research Paper No. 19/2010.

http://digitalcommons.osgoode.yorku.ca/clpe/86 


\section{OSGOODE}

OSGOODE HALL LAW SCHOOL

YOR K U N I VERSITY

\section{OSGOODE HALL LAW SCHOOL}

Comparative Research in Law \& Political Economy

RESEARCH PAPER SERIES

Research Paper No. 19/2010

The Long Shadow OF Colonialism: The ORIGINS OF THE

DOCTRINE OF EMERGENCY IN INTERNATIONAL HUMAN RIGHTS LAW

John Reynolds

Editors:

Peer Zumbansen (Osgoode Hall Law School, Toronto, Director, Comparative Research in Law and Political Economy)

John W. Cioffi (University of California at Riverside)

Lisa Philipps (Osgoode Hall Law School, Associate Dean Research)

Nassim Nasser (Osgoode Hall Law School, Toronto,

Production Editors)

Comparative Research in Law \& Political Economy 
CLPE Research Paper 19/2010

Vol. 06 No. 5 (2010)

\title{
John Reynolds
}

\section{The Long Shadow of Colonialism: The Origins of the Doctrine of Emergency in International Human Rights Law}

\begin{abstract}
Amidst the post-war turn to transcend international law's traditional power structures in the narration and codification of individual rights, colonial interests and legal philosophies retained an influence on the framing of human rights discourse. This essay explores the extent to which the particular conception of the 'state of emergency' that was distilled into the normative framework of international human rights law at its inception stemmed specifically from Britain's traditions of colonial governance and legislation. The evolution of emergency law is traced from martial law in England and the 'first empire', through British emergency legislative codes in Ireland and India in the nineteenth century, to the wholesale resort to emergency powers in the colonies as the empire began to fragment. The genesis of the emergency derogation provisions in the International Covenant on Civil and Political Rights and European Convention on Human Rights is appraised in the light of the colonial emergency context that formed the backdrop to their drafting. The essay argues that the accommodation of colonial interests at that point embedded a hegemonic legal tool that remains ripe for exploitation by regimes of all stripes inclined to repress opposition and dissent in a 'post-colonial' era. In the illumination of the colonial shadows from which the doctrine of emergency emerged, the state of emergency is revealed as a vehicle for law's violence, grounded in dynamics of domination.
\end{abstract}

Keywords: colonialism, British empire, martial law, rule of law, state of emergency, emergency powers, derogation, state of exception

JEL Classification: K33

John Reynolds

Ph.D. Candidate, Government of Ireland Scholar

Irish Centre for Human Rights

National University of Ireland, Galway.

john.j.reynolds@gmail.com. 


\title{
The Long Shadow of Colonialism: The Origins of the Doctrine of Emergency in International Human Rights Law
}

\author{
John Reynolds ${ }^{*}$
}

\begin{abstract}
[A]ccepting the reality of being a colonizer means agreeing to be a nonlegitimate privileged person, that is, a usurper. To be sure, a usurper claims his place and, if need be, will defend it by every means at his disposal. This amounts to saying that at the very time of his triumph, he admits that what triumphs in him is an image which he condemns. His true victory will therefore never be upon him: he need only record it in the laws and morals. For this he would have to convince the others, if not himself. In other words, to possess victory completely he needs to absolve himself of it and the conditions under which it was attained. This explains his strenuous insistence, strange for a victor, on apparently futile matters. He endeavours to falsify history, he rewrites laws, he would extinguish memories-anything to succeed in transforming his usurpation into legitimacy.
\end{abstract}

-Albert Memmi, The Colonizer and the Colonized ${ }^{1}$

\section{INTRODUCTION: THE DISCOURSE OF EMERGENCY AND EXCEPTIONALISM}

The fundamental quagmire of international law as it has developed in modern times is the tension between the political and economic interests of nation-states and the rights and freedoms of individuals. A state of perceived 'emergency' or 'exception' ${ }^{2}$ has long been understood as only exacerbating this tension. ${ }^{3}$ The more extreme the perceived exigency, the greater the temptations to disregard constitutional structures and expand executive power, at the expense of civil liberties and accountability. The advent of an international system for the

\footnotetext{
* Government of Ireland Scholar and Ph.D. Candidate, Irish Centre for Human Rights, National University of Ireland, Galway. This draft is based on a paper presented at: "Concerning States of Mind, Disturbing Minds of States", the Third Annual Conference of the Toronto Group for the Study of International, Transnational \& Comparative Law, 29-30 January 2010, Panel: Law, State and Empire. The author would like to thank Kathleen Cavanaugh, David Dyzenhaus, Michelle Farrell and Sujith Xavier for their insights.

${ }^{1}$ Albert Memmi, The Colonizer and the Colonized 118 (Howard Greenfeld trans., Earthscan Publications 1990) (1965).

2 The related terms 'state of exception', 'state of emergency' and 'state of siege' originate from a range of political contexts and legal systems, and while deviating in their specific definitions, can all be broadly understood as descriptive of a crisis situation in fact that provides justification for digression from principles otherwise established in law. The expression 'public emergency' is that which is used in the international legal instruments referred to herein; accordingly 'public emergency' and 'state of emergency' are the terms that will generally be employed to refer to situations of perceived threat as they relate to human rights law. The term 'state of exception' is used with a broader construction in mind, encompassing all situations of exception from 'normal' political and juridical orders.

${ }^{3}$ See, for example, Cecil T. Carr, Crisis Legislation in Britain, 40 Columbia L. Rev. 1309, 1324 (1940): "In the eternal dispute between government and liberty, crisis means more government and less liberty".
} 
protection of human rights has not fundamentally altered the state's capacity or tendency to succumb to such temptations.

In spite of extensive evidence of abuse, the discourse surrounding the doctrine of emergency generally fails to deviate from, or challenge, the presumption that provision for emergency measures is nonetheless legitimate, indeed imperative. In the context of international human rights law, emergency derogations are widely considered to be a "necessary evil"; a "realistic compromise". ${ }^{5}$ Much legal analysis of states of emergency has instead traditionally focused on the mechanics of derogations or on the tendency toward abuse of the system as an unfortunate side-effect of a human rights disclaimer that is assumed as indispensable. ${ }^{6}$ The origins and underpinnings of that assumption have rarely been questioned. ${ }^{7}$

In addition, both the states of emergency/derogations and 'war against terrorism'/exceptionalism discourses often lack historical perspective; ${ }^{8}$ failing to explore the genesis of emergency powers and their underpinnings in both domestic constitutional law and international human rights law. ${ }^{9}$ While the post-war human rights movement may have heralded some progress in transcending international law's traditional state-centric power structures, the European colonial mindset and legal philosophy retained an influence over the framing of international human rights law itself. The doctrine of emergency is one cavernous chink in the armour of rights protection, colliding as it does with any counter-hegemonic tendencies within international human rights law.

This essay aims to add some historical perspective; to examine the origins of the doctrine of emergency in order to inform contemporary debates and to cast some light on the limitations

\footnotetext{
${ }^{4}$ Sarah Joseph, Jenny Schultz \& Melissa Castan, The International Covenant on Civil and Political Rights: Cases, Materials, and Commentary 824 (2004).

${ }^{5}$ Scott N. Carlson \& Gregory Gisvold, Practical Guide to the International Covenant on Civil and Political Rights 33 (2003).

${ }^{6}$ See, for example, Thomas Buergenthal, To Respect and to Ensure: State Obligations and Permissible Derogations, in The International Bill of Rights: The International Covenant on Civil and Political Rights (Louise Henkin ed., 1981), Daniel O'Donnel, States of Exception, 21 Rev. Int. Comm. Jurists 52 (1978); Carlson \& Gisvold, supra note 5, at 33-36; Joseph, Schultz \& Castan, supra note 4, at 823-836; International Commission of Jurists, States of Emergency-Their Impact on Human Rights: A Comparative Study (1983).

${ }^{7}$ In referring to the discretion of states to derogate from their human rights obligations as the "Achilles' heel of the human rights doctrinal corpus", Balakrishnan Rajagopal is one scholar who has called for that assumption to be questioned. See Balakrishnan Rajagopal, International Law from Below 176 (2003).

${ }^{8}$ For example, seminal texts on states of emergency in international law often devote little more than footnotes in their introductory pages to the history of concepts of emergency. See, for example, Jaime Oraa, Human Rights in States of Emergency in International Law (1992).

${ }^{9}$ Notable exceptions include Anna-Lena Svensson-McCarthy, The International Law of Human Rights and States of Exception (1998); and Oren Gross \& Fionnuala Ní Aoláin, Law in Times of Crisis: Emergency Powers in Theory and Practice (2006).
} 
of human rights law. Delving back into British colonial history, ${ }^{10}$ in particular, allows us to understand the emergency as a technique of governance and instrument of control, rather than a purely reactive and temporary response to an isolated crisis. Owing much to Britain's influence at the advent of the institutionalisation of human rights - a time when recourse was being made to wholesale emergency powers in the empire in order to quell resistance, violent and non-violent alike-the concept of emergency has been embedded in the doctrinal corpus of international human rights law. This is predicated on an accepted perception of it as the latter (temporary response), when in reality it has continued to be used widely as the former (technique of governance and instrument of control).

In examining the colonial origins and mutations of this particular facet of modern law, the theoretical terrain upon which this essay is written can be situated within the broad ambits of postcolonial critique and third world approaches to international law. ${ }^{11}$ It considers the extent to which emergency was central to colonial rule; and the consequent knock-on effects on the development of western legality and, in turn, international human rights law. Against a broader backdrop of the formative influence of colonialism on modern international law, ${ }^{12}$ we can seek to ascertain how the experience of colonial emergency may inform contemporary 'rule of law' debates. In the post-colonial era, the supposed friction between sovereign power and normative legal rule maintains a constant presence in the conceptualisation of the state. This friction is central to the growing body of political and legal theory on the 'state of exception', a distinct theoretical realm into which the paper ultimately necessarily veers as it seeks to deconstruct the colonial in order to understand and inform the modern.

The essay begins with a brief sketch of the evolutionary path from martial law in England and the 'first empire', to emergency legislative codes in Ireland in the nineteenth century and beyond in the early twentieth century (section II), to the declaration of states of emergency in numerous British colonies in the years following the Second World War (section III). The latter provides insight into the historical, political and legal environment at the inception of an

\footnotetext{
${ }^{10}$ While a review of the colonial history of other European powers would also make for interesting study, this paper is focused on British colonialism as the most pervasive instance of emergency rule and legislation.

${ }^{11}$ On third world approaches, see, for example, Frederick E. Snyder \& Surakiart Sathirathai, Third World Attitudes to International Law: An Introduction (1987); Antony Anghie, Bhupinder Chimni, Karin Mickelson \& Obiora Okafor (eds.), The Third World and International Order: Law, Politics and Globalization (2003); Bhupinder Chimni, Third World Approaches to International Law: A Manifesto, 8 Int. Community L. Rev. 3 (2006); Richard Falk, Balakrishnan Rajagopal \& J. Stevens (eds.), International Law and the Third World: Reshaping Justice (2009).

${ }^{12}$ Prominent voices in Third World international legal scholarship have concluded that "[r]ather than seeing colonialism as external and incidental to international law, an aberration that could be quickly remedied once recognized," colonialism must be understood more drastically as "central to the formation of international law." See Antony Anghie \& Bhupinder Chimni, Third World Approaches to International Law and Individual Responsibility in Internal Conflicts, 2 Chinese J. Int'I. L. 77, 84 (2003). See also Antony Anghie, Imperialism, Sovereignty and the Making of International Law (2005).
} 
international system for the protection of human rights. An appraisal of the genesis of the derogations/state of emergency provisions in the International Covenant on Civil and Political Rights and European Convention on Human Rights, and Britain's particular influence on those provisions (section IV), can be held to support an argument that the particular conception of emergency that was distilled into the normative framework of international human rights law was influenced heavily by British traditions of colonial governance and legislation. A brief review of the subsequent resort to the derogations procedure in practice (section $\mathrm{V}$ ) lends further weight to that claim. In light of all this, elements of the doctrine of emergency as it has developed in international law can be re-appraised (section VI). The colonial framework through which states of emergency are explored in this paper also provides an additional perspective to debates attempting to theorise the state of exception within or beyond law (section VII).

\section{THE EVOlUtion Of THE DOCTRINe OF EMERGENCY}

The employment of exceptional measures to deal with crisis situations is not a recent phenomenon. The genesis of the idea of special emergency powers can be traced as far back as the aesymneteia, the 'elected tyrant' in whom the people of ancient Greece vested absolutist powers as a temporary exigency when their cities were under threat. ${ }^{13}$ Analogy is also drawn to the institution of the Roman 'dictatorship' that spanned three centuries of the Republic, ${ }^{14}$ as well as to the Roman law doctrine of iustitium. ${ }^{15}$ Contemporary conceptions of the state of emergency are also often equated with the civil law notion of the state of siege (l'état de siège) that was spawned during the French Revolution, first codified by a Constituent Assembly decree of 8 July 1791, and remains embedded in, amongst others, the French constitution. ${ }^{16} \mathrm{My}$ focus here, however, is on the British common law traditions of martial law and emergency legislative systems, and their consequent legacy as it relates to contemporary international human rights law.

\footnotetext{
${ }^{13}$ See Aristotle, Politics 73-74 (Benjamin Jowett trans., Batoche Books 1999).

${ }^{14}$ For an overview of the functioning of the Roman Dictatorship, see Clinton L. Rossiter, Constitutional Dictatorship: Crisis Government in the Modern Democracies 15-28 (1948).

${ }^{15}$ For an interpretation and analysis of iustitium, see Giorgio Agamben, State of Exception 41-51 (trans. Kevin Attell, University of Chicago Press 2005) (2003). Agamben (at 47-48) asserts that the iustitium is the appropriate parallel to be drawn with the modern state of exception, not the Roman dictatorship.

${ }^{16}$ See Article 36 of the Constitution of 1958. For analysis of the state of siege, see Théodore Reinach, De l'état de siege: Étude historique et juridique (1885).
} 


\section{A. Martial LaW in Britain and the Colonies}

The concept of martial law has its roots in medieval England, where it operated as what would now be commonly referred to as 'military law' - a system of regulations for the maintenance of order and discipline within the armed forces. From the fourteenth century, however, in addition to applying to soldiers or sailors in active service, it was used against civilians: "rebels and traitors, discharged soldiers and sailors, thieves, brigands, vagabonds, rioters, publishers and possessors of seditious books, even poachers, were condemned or threatened with the justice of martial law". ${ }^{17}$

Described as a "summary form of criminal justice ... independent of the established processes of the common law courts", ${ }^{18}$ it stood for a vast array of non-statutory, extraordinary powers aimed at dealing with violent crises. ${ }^{19}$ There has always existed a considerable lack of clarity in English legal theory as to the scope of those powers and the status of martial law. Certainly, martial law as it developed in Britain did not mean martial law in the sense of the complete suspension of ordinary law and the (temporary) government of the country by military tribunals. Beyond that, there are competing theories as to the legal foundations and parameters of martial law.

Many English legal scholars saw martial law as deriving from a common law "right of the Crown and its servants to repel force by force in the case of invasion, insurrection, riot, or generally of any violent resistance to the law" ${ }^{20}$ As such it operates within the perceived spatial parameters of a rule of law, with no normative differentiation in the legal system applicable in normal times vis-à-vis times of crisis. A.V. Dicey's argument that it entailed the "power of the government or of loyal citizens to maintain public order, at whatever cost of blood or property thus may be necessary" ${ }^{21}$ can be understood as a manifestation of the common law defence of necessity. Necessity, in terms of the latitude allowed for the use of emergency measures within the normal legal system, was construed broadly ('at whatever cost'). The power to deploy such measures "has in itself no special connection with the existence of an armed force", ${ }^{22}$ and it was contended that every subject of the Crown, whether soldier or civilian, was bound to assist

\footnotetext{
${ }^{17}$ J.V. Capua, The Early History of Martial Law in England from the Fourteenth Century to the Petition of Right, 36:1 Cambridge L. J. 152, 153 (1977).

${ }^{18} / d$. , at 152 .

${ }^{19}$ Gross \& Ní Aoláin, supra note 9, at 31.

${ }^{20}$ A.V. Dicey, Introduction to the Study of the Law of the Constitution 284 (8th ed. 1915).

${ }^{21} / d$., at 286.

${ }^{22} / d$., at 284 .
} 
with the suppression of riots. Once the force used was 'necessary', it was considered to have been fully lawful. Where the force used was 'excessive', those responsible were liable to be called before a jury for the use of unnecessary force. To further highlight the supremacy of the rule of law, Dicey invokes the fact that prosecution or punishment of non-military personnel for riot or rebellion by court-martial would be illegal. ${ }^{23}$

An alternative approach understands martial law as constituting a special system of military rule temporarily applicable in place of civilian rule during grave crises, but still nonetheless operating within an overarching rule of law, subject to certain constitutional constraints. As such, ordinary law is abrogated "only to the extent required by the overriding consideration of preserving the state", ${ }^{24}$ and the powers that are necessarily invoked, while extraordinary, are not exterior to the juridical order. This interpretation of martial law sits closest to the civil law état de siège, under which "the authority ordinarily vested in the civil power for the maintenance of order and police passes entirely to the army". ${ }^{25}$ While military tribunals may supersede the jurisdiction of the courts, "the suspension of law involved in the proclamation of a state of siege is a thing fully recognised by the constitution". ${ }^{26}$ Dicey claimed that martial law in this sense "is unknown to the law of England" (that is, under English law, authority would never pass entirely to the military), an assertion which serves as "unmistakable proof of the permanent supremacy of the law under our constitution". Significantly, however, he footnotes that statement as having "no reference to the law of any other country than England, even though such country may form part of the British Empire". ${ }^{27}$

While drawn from quite distinct theoretical perspectives and ostensibly different in form, the substantive effects of these two approaches do not diverge hugely. Both ultimately rest on the

\footnotetext{
${ }^{23}$ Dicey cites the granting of a writ of habeas corpus in the case of United Irishmen leader Wolfe Tone-on the morning that he was due to be executed in 1798 under a court-martialled sentence-as the epitome of the "noble energy with which judges maintained the rule of regular law, even at periods of revolutionary violence". Id., at 289. This argument is compromised by certain facts which Dicey fails to note - that Wolfe Tone's brother Matthew, and numerous other leaders of the Society of United Irishmen, were executed after being tried by court-martial; and that Wolfe Tone's case was somewhat distinct (and therefore unrepresentative) in that the civil court judge who granted the habeas corpus writ for his release, Chief Justice Lord Kilwarden, was a former mentor of his, with close family connections, who five years previously as Attorney-General had helped Tone to flee to America to escape prosecution. See Marianne Elliott, Wolfe Tone: Prophet of Irish Independence 398399 (1989); Thomas Pakenham, The Year of Liberty: The Great Irish Rebellion of 1798 344-345 (1969); Patrick C. Power, The Courts-Martial of 1798-99 (1997); Henry Boylan, Theobald Wolfe Tone 132-133 (1981); Seán Cronin, For whom the hangman's noose was spun: Wolfe Tone and the United Irishmen (1991). Unaware of the application for habeas corpus being made on his behalf, Tone had attempted suicide in prison earlier that morning of his planned execution, and later died from the wounds.

${ }^{24}$ R.J. Sharpe, The Law of Habeas Corpus 108 (1976).

${ }^{25}$ Dicey, supra note 20 , at 283-284.

${ }^{26} / d$., at 289 .

${ }^{27}$ Id. , at 283-284.
} 
justification of necessity, albeit at different times - in the case of the common law martial law, the exercise of power must be shown post facto to have met the test of necessity in order to preclude liability; in the case of the state of siege exceptional regime of military rule, necessity arises ex ante in the justification of the invocation of the emergency itself.

A third view holds that martial law is not law at all, but rather, as Lord Wellington famously stated in 1851 in relation to the use of martial law in Ceylon, the "will of the General who commands the army". ${ }^{28}$ It is a practical means of discharging the common law duty of restoring order. ${ }^{29}$ This model places emergency powers outside the remit of law, with the General's will (which nonetheless has force of law) constrained only by his practical judgment. The exigencies of the situation may justify (and indemnify) such extra-legal measures, without incorporating them into the ordinary system of laws.

Martial law in Britain remained restricted to instances of war and open rebellion until the midsixteenth century, in which context it was regularly used as an offensive rather than defensive measure. During the 'Pilgrimage of Grace' rebellion in 1537, for example, Henry VIII instructed one of his commanding lieutenants to "continue to proceed by martial law until the country was in such terror as to insure obedience". ${ }^{30}$

From the mid-1550s, the Crown authorities gradually expanded the jurisdiction of martial law into spheres that had hitherto been the exclusive domain of regular criminal law. At that point, a period of severe economic depression, martial law was invoked as a peacetime measure for the first time, and began to be used as a means of class and political repression against "general undesirables with no apparent means of support" and inconvenient opposition to the Crown. ${ }^{31}$ With some initial hesitation as to how it might be perceived, this shift was introduced cautiously, with care taken to ensure that the first to be subjected to the new policy were not too close to home: in 1556 Mary I authorised the Marshal of the army in Ireland to proceed against 'general undesirables' there by martial law. ${ }^{32}$ In 1562, Thomas Radcliffe, $3^{\text {rd }}$ Earl of Sussex, recommended to the Queen that an English-born ruler be appointed to govern the Irish province of Munster, with the "authority to execute the martial law in times of necessity, but only against persons that have no possessions". ${ }^{33}$ In the meantime, martial law had been

\footnotetext{
${ }^{28}$ Hansard, cxv 880 (1 April 1851).

${ }^{29}$ See Lord McDermott, Law and Order in Times of Emergency, 17 Juridical Rev. 1 (1972).

${ }^{30}$ Capua, supra note 17, at 161, citing Letters and Papers Foreign and Domestic of the Reign of Henry VIII, XII, i, 479.

${ }^{31}$ Capua, supra note 17 , at 164 .

${ }^{32}$ Calendar of State Papers, Ireland, 1509-1573, at 134.

${ }^{33}$ Calendar of the Carew Manuscripts, 1515-1574, at 336.
} 
introduced in England to silence and intimidate those opposed to the Tudors' religious policy, and to suppress sedition. ${ }^{34}$ This resort to martial law in times of peace continued under subsequent monarchs, including the Stuart kings who imposed the 'justice of martial law' as a means of punishing civilians, including by execution. The peacetime use of martial law was then outlawed by parliament-with Charles I asked to revoke and annul existing commissions of itby virtue of the Petition of Right in $1628 .{ }^{35}$ While it was unclear whether the Petition of Right was intended to preclude the use of martial law in times of war, the prevailing view holds that "[u]ndoubtedly martial law as employed in the later sixteenth century against civilians was the target of the prohibition", and it would only henceforth be applied to regulate affairs within the King's army. ${ }^{36}$

Following the Petition of Right, the use of martial law fell into desuetude in England. ${ }^{37}$ As Britain continued to build up its colonial empire abroad, however, the government resorted increasingly frequently to martial law in the colonies. It became "an essential part of the security apparatus of many parts of the empire". ${ }^{38}$ Abandoned at home partly because of its perceived tyrannical character, the imposition of martial law against the non-British native

\footnotetext{
${ }^{34}$ See Capua, supra note 17, at 164-166.

35 Id., at 171-172.

${ }^{36}$ See id., at 171, note 77: "the debates in the Commons seem to suggest that the framers of the Petition did not intend to prohibit the use of martial law in the army when it was actually in the field".
}

${ }^{37}$ Whilst recollections as to when martial law was last invoked in England range from 1689 [James G. Randall, Constitutional Problems under Lincoln 143 (1926)] to 1800 [Rossiter maintains that martial law was last resorted to in England on three occasions during the eighteenth century, see Rossiter, supra note 14, at 143], it is not disputed that by the end of the eighteenth century it had been phased out of practice completely.

${ }^{38}$ R.W. Kostal, A Jurisprudence of Power: Victorian Empire and the Rule of Law 10 (2005). Martial law was exercised in parts of South Africa by the British in 1835-36, 1846-47, 1850-53, 1899-1902, and 1906-08 in relation to various confrontations with both indigenous African populations and rival Boer colonialists. See, for example, Charles Townshend, Martial Law: Legal and Administrative Problems of Civil Emergency in Britain and the Empire, 1800-1940, 25 The Historical J. 167, 176-182 (1982). The matter of the use of martial law during the Boer War came before the Judicial Committee of the Privy Council in the case of $E x$ parte D.F. Marais, [1902] A. C. 109. The judgment removed a major restriction on the exercise of martial rule powers in holding that the trial of civilians by military tribunals was not barred by the fact that the ordinary courts remained open. Martial law was similarly availed of by the British authorities in Canada to suppress the Quebec patriots' rebellion between 1837-39. See Svensson-McCarthy, supra note 9, at 22. The Petition of Right did not extend to Ireland, where martial law was declared by the British in response to the uprisings of $1798,1803,1916$ and 1920-21. Townshend, ibid., at 184, notes that martial law was kept in force for some four months in 1916 (the Easter rising was quelled in less than a week), and it was under General Maxwell's regime of martial law that the "politically disastrous" executions of the Irish leadership were carried out. In 1921 the British courts consistently followed the Marais precedent regarding the use of the justice of martial law while the ordinary courts remained open. See, inter alia, The King v. Allen [1921] 2 Ir. R. 241; The King (Garde) v. Strickland [1921] 2 Ir. R. 317; The King (Ronayne and Mulcahy) v. Strickland [1921] 2 Ir. R. 333. Regimes of martial law were also regularly imposed in India: for a reflection on the Amritsar massacre of 1919, "an incident which was neither the beginning nor the end of martial law" in India, see Nasser Hussain, Towards a Jurisprudence of Emergency: Colonialism and the Rule of Law, 10 Law \& Critique 93 (1999) [quote at 94]; on the suppression of the Indian Mutiny in 1857-58, facilitated by martial law, see Saul David, The Indian Mutiny, 1857 (2002). 
populations in "that standard locale of political experimentation, the colonies", ${ }^{39}$ proved considerably less controversial. Martial law was approved of as a mechanism to protect British interests over those of the native other. Throughout the empire, from the Caribbean to Asia, the Crown's agents invoked martial law to suppress native protests against anything from colonial taxes to agrarian policies to maltreatment of slaves. ${ }^{40}$

In these various instances, the raison d'être of the resort to martial law was seen as the preservation of the "good order and tranquillity" ${ }^{41}$ of British rule in the colony concerned; that is, the suppression of disobedience and silencing of dissent against colonial government. Such disobedience and dissent from the native population served to plunge the colony into "a state of the greatest alarm and danger", thus offering justification for the invocation of martial law. Once invoked, the result would often be a period of violence under martial law that appeared to transgress the blurry threshold of 'necessity' but was nonetheless justified as legal. The perceived legitimacy of adopting extraordinary measures to maintain public order, at whatever cost of blood or property may be necessary, as Dicey had suggested, can be extrapolated from the parliamentary debate regarding the use of martial law in Ceylon. While Gladstone questioned whether the action taken by the military commander "has not been done under the law so to be called, but under a necessity which is above the law", Robert Peel emphasised "the right, when the necessity arises ... to proclaim martial law for the safety of the colony" ${ }^{42}$ In that context, the safety of the colony is clearly understood as denoting the safety of the agents of colonialism, and of Britain's control of, and interests in, the colony: "[t]he threat of martial law was an essential resource for the officials who maintained the British Empire, as they sought to defend imperial interests in the midst of an often very hostile local population". ${ }^{43}$

\footnotetext{
${ }^{39}$ Mark Neocleous, From Martial Law to the War on Terror, 10:4 New Crim. L. Rev. 489, 493 (2007).

$4^{\circ}$ Including in Demerara (1823), Barbados (1805, 1816), Ceylon (1848), Cephalonia (1849), St. Vincent (1863), and, perhaps most famously, in Jamaica in 1865 , "when a servile revolt ... was put down with the severity which one might expect from planter militia". Charles Fairman, The Law of Martial Rule and the National Emergency, 55 Harv. L. Rev. 1253, 1254 (1942). For further detail see Bernard Semmel, Jamaican Blood and the Victorian Conscience: The Governor Eyre Controversy (1962), and Kostal, supra note 38 .

${ }^{41}$ Letter to Lieutenant-Colonel Goodman, Commandant of the Georgetown Militia, from colonists in Georgetown and its vicinity, 22 January 1824. Reproduced in Joshua Bryant, Account of the Insurrection of the Negro Slaves in the Colony of Demerara 19 (1824), at 104 .

$4^{2}$ Select Committee on Ceylon, Second Report, 12 Sess. Papers, paras. 5476-5477 (1850), quoted in Fairman, supra note 40, at 1260-1261.

${ }^{43}$ David Dyzenhaus, The Puzzle of Martial Law, 59 Univ. Toronto L. J. 1 (2009).
} 


\section{B. From Martial LaW to Emergency Codes}

While the nineteenth century was marked by the widespread use of martial law throughout the empire, it also witnessed a parallel evolution from martial law to emergency legislative codes. The assimilation of emergency powers into written law by Britain's colonial authorities was most vociferously effected not in the distant corners of the empire but across the water in Ireland, fully annexed by Britain through the Act of Union in 1800 but governed as a colony for all intents and purposes. Martial law was imposed by the King's viceroy in Ireland during the attempted rebellions of 1798 and 1803 in order to "punish all persons acting, aiding, or in any manner assisting the said rebellion" ${ }^{44}$ Between then and the Easter rising of 1916, however, the use of martial law as a reactive measure was foregone in favour of a more constant and pervasive framework for dealing with 'disturbances' in Ireland. Thus, a steady stream of Insurrection Acts, Habeas Corpus Suspension Acts and Coercion Acts flowed into Ireland from the beginning of nineteenth century, with the effect that "[d]uring the thirty-five years which preceded Catholic emancipation the ordinary laws of a peaceful country were almost uninterruptedly superseded by a course of exceptional measures" ${ }^{45}$ Peel accordingly pointed out in the course of the parliamentary debate on the Catholic Relief Bill in 1829 that "for scarcely a year during the period that has elapsed since the Union has Ireland been governed by the ordinary course of the law".$^{46}$ Formal Catholic emancipation did come with the passing of that bill into law in 1829, but "proved no more of a panacea than the Union before it", ${ }^{47}$ in terms not only of the continued disenfranchisement of the Irish peasant population on economic instead of religious grounds, but also in terms of the unrelenting enactment of

\footnotetext{
${ }^{44} 43$ Geo. III, C.117; 39 Geo. III, C.11.

${ }^{45}$ See Isaac S. Leadam, Coercive Measures in Ireland, 1830-1880 7 (1886).

${ }^{46}$ Hansard 2, xx, 741-2 (5 March 1829). Peel's statement provides a synopsis of the series of Insurrection Acts and Habeas Corpus Suspension Acts during that period: "In 1800 we find the Habeas Corpus Act suspended, and the Act for the suppression of the rebellion in force. In 1801 they were continued. In 1802, I believe, they expired. In 1803, the insurrection in which Emmett suffered broke out, Lord Kilwarden was murdered by a savage mob, and both Acts of Parliament were renewed. In 1804 they were continued. In 1805 renewed. In 1806 the west and south of Ireland were in a state of insubordination, which was with difficulty repressed by the severest enforcement of the ordinary law. In 1807, in consequence chiefly of the disorders that had prevailed in 1806, the Act called the Insurrection Act was introduced. It gave power to the Lord-Lieutenant to place any district, by proclamation, out of the pale of the ordinary law, it suspended trial by jury, and made it a transportable offence to be out of doors from sunset to sunrise. This Act continued in force in 1807, 1808, 1809, and to the close of the session of 1810 . In 1814 the Insurrection Act was renewed. It was continued in $1815,1816,1817$. In 1822 Habeas Corpus Act suspended and Insurrection Act again revived, and continued during the years 1823, 1824, 1825. In 1825 the temporary Act intended for the suppression of dangerous associations, and especially of the Roman Catholic Association, was passed. It continued during 1826, 1827, and expired in 1828. The year 1829 brings with it the demand for a new Act to suppress the Roman Catholic Association."

${ }^{47}$ Virginia Crossman, Emergency Legislation and Agrarian Disorder in Ireland, 1821-41, 27:108 Irish Historical Studies $309,309$. (1991).
} 
repressive legislation that followed. By the halfway point of the nineteenth century, Ireland had been ruled under 'the ordinary course of the law' for only five years of the preceding fifty. ${ }^{48}$

One of the first statutes to institute a system of emergency law, the 1833 Act for the More Effective Suppression of Local Disturbances and Dangerous Associations in Ireland, ${ }^{49}$ is described by Brian Simpson as "the ancestor of the modern code of emergency law". ${ }^{50}$ The Lord-Lieutenant, the King's viceroy, was empowered to trigger the application of the law by declaring a county to be affected by local disturbances or 'dangerous' organisations to the extent that extraordinary powers not allowed for by the common law were required. As such, the Lord-Lieutenant was essentially mandated to declare what we now know as a 'state of emergency'. He was given powers to suppress meetings and impose curfews, with offences under the Act to be tried by courts-martial. Nothing done under the Act could be questioned in any court of law. The ostensible aim of the legislation was to stifle agitation from the Irish peasantry. There was a distinct divergence of opinion in Westminster, however, as to the level of violence that was actually occurring in Ireland at the time. At the second reading of the Bill in the House of Commons, John Key MP spoke of what was reported to him as a state of "disgraceful insubordination" ${ }^{51}$ prevailing in Ireland. Joseph Hume MP, on the other hand,

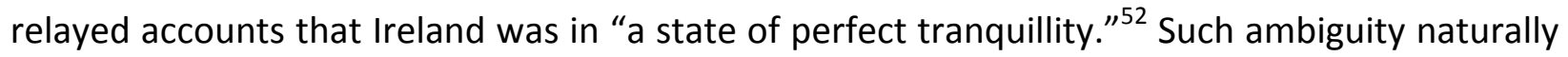
gives rises to suspicions that the degree of extant 'insubordination' may have been overplayed with a view to ensuring that more fundamental political interests would be served by the passing of the legislation. In this regard, the comments of the Earl of Roden in the House of Lords debate shed much light: he spoke of the importance of "suppressing agitation in Ireland" in order to preserve "the integrity of the empire". The protection of the Protestant interest by the British government was essential; otherwise "it would be utterly impossible to prevent a Repeal of the Union, or, in other words, a dismemberment of the Empire" ${ }^{53}$ Viewed through a lens that recognises the primacy of the preservation and integrity of the empire, the motivation behind the sweeping deprivation of constitutional rights that the 1833 Act heralded in Ireland comes into clearer focus. Such an analysis is consonant with the British colonial outlook whereby every instance of disorder or opposition in a given colony was "considered from an empire-wide perspective". ${ }^{54}$

\footnotetext{
${ }^{48}$ John L. Hammond, Gladstone and the Irish Nation 16 (1938).

49 1833, 3 Will. IV, C. 4 .

${ }^{50}$ A.W.B. Simpson, Human Rights and the End of Empire: Britain and the Genesis of the European Convention 79 (2001).

${ }^{51}$ Hansard, vol. 16 c.450 (HC Deb 8 March 1833).

${ }^{52}$ Hansard, vol. 16 c.406 (HC Deb 8 March 1833).

${ }^{53}$ Hansard, vol. 16 C.1312-1313 (HL Deb 1 April 1833).

${ }^{54}$ Frank Füredi, Colonial Wars and the Politics of Third World Nationalism 156 (1994).
} 
The web of emergency legislation continued to be spun throughout the nineteenth century. The Crime and Outrage Act of 1847 was passed during the Great Famine in response to the "system of terror" that Sir George Grey claimed that English landlords were subjected to by the Irish peasantry; ${ }^{55}$ a populace that Britain and the landlords had exploited to the point of "poverty, disaffection, and degradation without a parallel in the world." ${ }^{56}$ This law empowered the Lord-Lieutenant to proclaim districts 'disturbed', and to impose restrictions accordingly. Other notable additions included further Habeas Corpus Suspension Acts (1848-49, 1866-69), as well as the Protection of Life and Property (Ireland) Act of $1871^{57}$ and the Act for the Better Protection of Person and Property in Ireland of $1881 .{ }^{58}$ Both of the latter allowed for detention of suspects without charge or any form of judicial supervision. The Prevention of Crime (Ireland) Act of $1883^{59}$ "conferred a variety of other repressive powers on the Irish [colonial] authorities; jury trial could be abolished for certain offences, meetings prohibited, newspapers seized and suspects out of doors at night arrested without warrant." ${ }^{\prime 60}$ The trend continued thus through the turn of the century and rising cultural, political and socio-economic resistance to British rule; the last major act of legislation that allowed for emergency regulations before Irish independence was the Restoration of Order in Ireland Act of 1920, essentially an extension of the Defence of the Realm Act of 1914 that had been enacted in Britain upon the outbreak of the First World War. The 1920 Act marked an attempt to increase convictions of Irish nationalist leaders while averting the need to impose martial law. ${ }^{61}$ Thus, the case of Ireland from 1800 until its independence in 1922 can be seen as the embryo in which the institutionalisation of emergency codes and the notion of a permanent exception developed.

The statement of the Earl of Roden referred to above is largely representative of the thinking of the British political establishment during this time, and helps to explain why Britain took such extensive measures to legislate for the continuing repression of any form of opposition to colonial rule in Ireland. There was a broader empire at stake, and palpable fear of a domino effect. Ireland had been subjugated by Britain for longer than most of the rest of the empire; its

\footnotetext{
${ }^{55}$ Hansard, 20 November 1847, cited in Leadam, supra note 45, at 20.

${ }^{56}$ The Times, 24 March 1847, quoted in Christopher Morash \& Richard Hayes, Fearful Realities: New Perspectives on the Famine (1996).

${ }^{57} 34$ Vict. C. 25 .

${ }^{58} 44$ Vict C. 4 .

5946 Vict. c. 25 .

${ }^{60}$ Simpson, supra note 50 , at 80 .

${ }^{61}$ In the latter respect it was ultimately unsuccessful; the British authorities declared martial law in December 1920 as Irish resistance escalated.
} 
anti-colonial resistance had reached a more advanced stage. If Ireland was allowed to go, the thinking went, it would signify an insecurity for Britain that could potentially reverberate around the empire. It was on this basis that Gladstone's bill proposing 'Home Rule' for Ireland in 1886 was defeated. The majority of MPs feared that a partially independent Ireland could herald the beginning of the dismemberment of the empire.

Instead, a domino effect of another sort can be identified. The use of martial law, long abandoned on mainland Britain, had been normalised in the overseas empire and spread throughout its vast reach. It was, however, a somewhat amorphous concept. As the traditional common law propensity to avoid elaborate codification of laws began to recede somewhat, the British authorities steadily developed an institutionalised system of emergency legislation in Ireland, as a more refined and defined alternative to martial law, and more pervasive in its application. The essence was the same, however: emergency codes created "a form of statutebased martial law in which the will of the executive is supreme" ${ }^{62}$ Such a system, it transpired, is exactly what was perceived as needed at home in Britain when the First World War broke out. The British authorities and military required broad and clearly-mandated powers to act decisively. The matrix of sweeping legislative powers enacted in Ireland - most notably the 1833 Act - thus provided a ready-made normative source for the series of Orders in Council that were authorised by a parent act, the Defence of the Realm Act (DORA) of $1914 .{ }^{63}$ Under this system, powers could be acquired, modified and enhanced by the executive without further reference to parliament. Thus, for example, executive detention, which had never been mentioned when the parent act went through parliament, was introduced in 1915 by Order in Council. ${ }^{64}$ Simpson notes that "[t]he structure of government under DORA closely resembled the situation in those colonial territories where the Governor and executive could force through any legislation desired" ${ }^{65}$

Having been based on a model developed in colonial territories, primarily in Ireland, this system would now spill over to much of the empire. A similar emergency code was exported to India under the 1915 Defence of India Act, whereby the Governor-General in Council was given free reign to enact rules for "the purpose of public safety and defence of British India". ${ }^{66}$ Emergency powers were continued after the war under the Anarchical and Revolutionary Crimes Act of

\footnotetext{
${ }^{62}$ A.W.B. Simpson, Round Up the Usual Suspects: The Legacy of British Colonialism and the European Convention on Human Rights, 41 Loyola Law Review 629, 640 (1996).

${ }^{6} 4 \& 5$ Geo. V, C. 29.

${ }^{64}$ Simpson, supra note 50 , at 81 .

${ }^{6}$ Id.

${ }^{66}$ Simpson, supra note 62 , at 646 .
} 
1919, the Criminal Tribes Act of 1924 and the Bengal Criminal Law Amendment Act of 1925, with significant consequences in terms of the controlled residence, forcible transfer and internment of Indians. ${ }^{67}$

In Palestine, under mandate rule following the First World War, the British authorities enacted the Palestine (Defence) Orders in Council of $1931^{68}$ and $1937 .{ }^{69}$ The legal situation created by those statutes bore substantial resemblance to that of Ireland under the Defence of the Realm legislation, with Britain's High Commissioner empowered to declare a public emergency in Palestine, whereupon collective punishment, property destruction, movement restrictions, deportation and detention became par for the course.

The evolutionary shift in colonial mentality towards a more defined and widely applicable emergency legislation system that had occurred was highlighted by an assertion of the Colonial Secretary with regard to the situation in Palestine during the 1930s. The declaration of martial law would, according to him, be avoided unless the rebellion became "so serious, widespread and effective, that there was a complete breakdown of the functions of civil government"; that is, effectively only in the case of full-scale war. Otherwise, the Colonial Secretary felt it "unwise on constitutional and practical grounds to mix up with emergency powers legislation the doctrine of Martial law." ${ }^{70}$ As opposition to Britain's rule intensified around the empire through the 1940s and 1950s, similar emergency powers to those developed in Ireland, India and Palestine would be invoked in many of Britain's colonial territories.

\section{SUNSET EMERGENCIES:}

\section{The Political, Cultural and Legal EnVironment in a Fading Empire}

With Britain's grip of the 'first empire' of its 'new world' settler colonies loosened upon the loss of the American colonies, it began to divert its gaze eastwards towards the lures of a 'second empire'. Britain's "imperial century" ${ }^{\prime 11}$ from 1815-1914 was marked by the assumption of direct political control over trading colonies in Asia, and successful scrambling in Africa. By the time the spoils of the First World War were distributed under League of Nations mandates, Britain had amassed an uninterrupted spine of colonial territories through Africa from the Cape to

\footnotetext{
${ }^{67}$ Id., at $647-648$.

${ }_{3}^{68}$ Government of Palestine Ordinances, Regulations, Rules, Orders and Notices 259 (19 April 1936).

${ }^{69} 2$ Government of Palestine Ordinances, Regulations, Rules, Orders and Notices 261 (20 March 1937).

${ }^{70}$ William Ormsby-Gore, Cabinet Memorandum: Palestine: Defence Orders in Council, CP 86 (37) P.R.O. W.O. 329618.

${ }^{71}$ Ronald Hyam, Britain's Imperial Century, 1815-1914: A Study of Empire and Expansion (2002).
} 
Cairo, and onwards through its mandate territories in the Middle East. ${ }^{72}$ Over the course of that century, the British empire had:

ceased to be an empire largely composed of communities of free peoples of British origin tied to Britain by trade regulations and naval power. It was now an empire including numerous peoples who were not British in origin and who had been incorporated into the empire by conquest and who were ruled without representation. ${ }^{73}$

Whilst glossing over matters of conquest and race that were certainly not absent from the earlier temporal period of Britain's imperial misadventures, most notably in Ireland and the Caribbean, this description is broadly representative of the shift in colonial paradigm that occurred as the empire's tentacles extended throughout Asia and Africa. Without the presence of significant communities of settlers to provide political support, and cultural and economic links to the metropole, Britain was inevitably more vulnerable to resistance to its rule in the 'second empire'.

The dissent and disobedience of the natives had always been perceived as a fact of colonial governance, long before the advent of 'third world' nationalism. ${ }^{74}$ Hence there had been strong insistence from Britain on recourse to the discretionary authority of the central executive in order to sustain a regime of conquest. With the rise of anti-colonial nationalism in Africa and Asia during the first half of the twentieth century coinciding with Britain's declining status as the world's dominant power, it became clear that it was facing a serious threat to the continuing integrity of the empire. India was at the forefront of such resistance, and the special powers measures of the $1920 \mathrm{~s}$ and $1930 \mathrm{~s}$, by which the British sought to counter an increasingly radical nationalism, evoked an idiom of terrorist threat and a shift towards special tribunals that would be instantly recognisable today. ${ }^{75}$ Britain's actions in this regard can be seen to have exemplified an emergent mechanism of governance "that comprehends and confronts a threat through an administrative rationality". ${ }^{76}$

\footnotetext{
${ }^{72}$ For a celebratory account of the reach of the empire at its height, spanning approximately a quarter of the world's land surface area, see, for example, Niall Ferguson, Empire (2004).

${ }^{73}$ P.J. Marshall, Empire and Authority in the later Eighteenth Century, 25:2 J. Imperial \& Commonwealth History 105, 115 (1987).

${ }^{74}$ Hussain, supra note 38 , at 100 .

${ }^{75}$ See Nasser Hussain, Hyperlegality, 10 New Crim. L. Rev. 514, 521-523 (2007), citing the Bengal Criminal Law Amendment Act of 1925 and the Bengal Emergency Powers Ordinance of 1931.

${ }^{76} / d$., at 523 .
} 
It was to this mechanism that Britain would resort as it became embroiled in more and more political and military struggles to maintain the stability and continued sovereignty of its colonial regimes at the advent of the UN era. Thus, its last major wave of colonial wars during the late 1940s and 1950s, were "euphemistically self-styled as 'emergencies" ${ }^{\prime \prime},{ }^{77}$ so that mass resistance could be dealt with by special powers enacted in the name of the restoration of normalcy (rather than the competing, and less flattering, narrative of resort to force to sustain hegemonic control). The post-war British political establishment "had every intention of retaining the empire", but "the use of force for the maintenance of the empire had become problematic ... international and domestic opinion posed limits" ${ }^{78} \mathrm{~A}$ communication from Lord Killearn in the Cairo embassy back to London emphasised that "the time has already gone in Egypt and in the Middle East as a whole when we can rely on force alone to maintain our position". ${ }^{79}$ Not just force, but force of law was required to suppress growing resistance to colonial rule throughout the empire. The 1948 "Panic in Whitehall", generated by the somewhat belated realisation ${ }^{80}$ that the foundations of the empire were crumbling, resulted in colonial officials looking "to special powers to give them a breathing space in which they could reclaim the initiative. When the normal forms of political management failed to contain the nationalist challenge, the calling of an emergency was always a plausible option" ${ }^{81}$ To this end Britain sought to rely on law and on the notion of emergency in order to preserve a perception of legitimacy, presenting its use of force in the colonies as having little to do with imperialist expansion, and relating rather to upholding 'law and order' under the duress of emergency. Analyses of British policy at this time have concluded that "every imperial response to anticolonial protest contained elements of an informal emergency, while every formal emergency possessed a political dimension". ${ }^{82}$

A shroud of administrative legality was used to conceal underlying political objectives in many of the colonies where Britain sought to suppress radical anti-colonial movements and to promote their more moderate counterparts. Hence the 'Gold Coast experiment' whereby

\footnotetext{
${ }^{77}$ Rajagopal, supra note 7, at 178.

${ }^{78}$ Füredi, supra note 54 , at 143.

${ }^{79}$ Public Record Office, FO 370/895, General Correspondence: Lord Killearn to Sir Maurice Peterson, 17 January 1944.

${ }^{80}$ Füredi sketches a dividing line between British government policies in the colonies pre and post 1948: "Whitehall's new attitude towards the problem of order in the colonies - expressed through a willingness to use special measures, emergencies and high-profile policing to manage political opposition - becomes apparent from early 1948. Until this period, especially up until mid-1947, Whitehall was comparatively relaxed about the problem of order in the colonies. Often it was the Colonial Office that tried to curb the enthusiasm of the local administration for enacting new special powers and emergencies." Füredi, supra note 54 , at $94-95$.

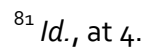

${ }^{82}$ Id., at 5.
} 
Britain sought to mitigate the challenge to its rule in Ghana through the quasi-solution of "semiresponsible government", as opposed to actual self-government or independence. ${ }^{83}$ In the late 1940s, in the Gold Coast and Malaya in particular, the state of emergency was used as a methodology of governance derived from the need to re-establish control over a deteriorating situation in order that it could be managed to Britain's advantage. States of emergency in these territories were declared by the respective colonial Governors under the Emergency Powers (Colonial Defence) Order in Council of 1939, which had decreed that:

the Governor may make such regulations as appear to him to be necessary or expedient for securing the public safety, the defence of the territory, the maintenance of public order and the suppression of mutiny, rebellion and riot, and for maintaining supplies and services essential to the life of the community. ${ }^{84}$

Interpreting their mandate extremely broadly, colonial governors invoked emergency powers not merely as a reactive mechanism to avert prevailing or imminent crises, but as calculated pre-emptive measures infused into the ongoing governance of their respective territories. ${ }^{85}$

Deployed as part of the colonial public relations machinery, fear of the native 'savage' became a dominant theme in Eurocolonial discourse as it related to Third World resistance. ${ }^{86}$ This fear dovetailed with the prevalent distrust of nationalism that fascism had provoked in Europe, and the pejorative connotation that the term had come to acquire as it gained traction in the colonies, particularly in Africa. ${ }^{87}$ These two elements, fear of the savage and concern over expressions of nationalism, were exemplified by the comments of Sir Charles Arden-Clarke, British governor in the Gold Coast, in describing Ghanaian political leader Kwame Nkrumah in a letter back to England in 1950 as "our local Hitler". ${ }^{8}$ In this vein the policy of deriding nationalism against imperial rule was a much adhered-to colonial tactic, and could be clearly witnessed in the way that emergencies were implemented.

\footnotetext{
${ }^{83}$ For the historical context see, for example, Martin Meredith, The State of Africa 17-29 (2005). For the perspective of the British colonial governor see Charles Arden-Clarke, Gold Coast into Ghana: Some Problems of Transition, 34:1 Int. Affairs 49 (1958).

${ }^{84}$ Section 6(1), Emergency Powers (Colonial Defence) Order in Council, 1939.

${ }^{85}$ Füredi, supra note 54, at 97, noting that: "In this climate, even relatively liberal administrators were busy integrating emergency powers into their overall strategy. So Sir John Macpherson, governor of Nigeria, passed 'legislation conferring emergency powers on the executive' in December 1948. Macpherson, like other governors, was planning ahead. Throughout the empire police forces and security arrangements were being reviewed and contingency plans drawn up."

${ }^{86}$ Rajagopal, supra note 7, at 179.

${ }^{87}$ For an insightful discussion of imperial attitudes towards Third World nationalism, see Füredi, at 109-139.

${ }^{88}$ Quoted in Meredith, supra note 83, at 19.
} 
Fascism was just one brush that opposition to colonial rule was tarred with. The spillover of the Cold War into colonial Africa and Asia was also very much apparent by the 1950s. The nationalist struggles throughout the British empire, as well as those in other European colonies (most notably Algeria), were depicted as evidence of the steady encroachment of communism and of the rising threat to Western values. The catch-all slur of 'terrorism' was also projected onto any dissent or resistance emanating from the colonised populations, and the same broad strokes were applied across the colonial canvas, from South America to Africa to east Asia. By way of just one example, one of the arguments used by a British constitutional commission to justify the suspension of the constitution in British Guiana in 1953 (an act characterised by the American consul at the time as a coup d'état) was that its minister for education had created an African and Colonial Affairs Committee which "declared support for the Mau Mau in Kenya and the Communist terrorists in Malaya". ${ }^{89}$ The use of emergency measures to repress the perceived communist threat went hand in hand with the economic objectives of colonialism. In the run-up to the declaration of the state of emergency in Malaya, for example, the colonial administrators had "demanded special powers for crushing trade unionism" from London, and "European plantation interests were vociferous in their demand for tough action". ${ }^{90}$

By consistently referring to 'terror' and couching the situations of increasing unrest in the colonies within the realm of criminality and public order rather than as political or economic resistance against the hegemony of the regime concerned, the colonial authorities were able to frame the situations as emergencies whereby special powers were needed to counter subversive terrorist, communist threats. A clear desire to render the political objectives of anticolonial nationalism invisible as a factor was manifest. Emphasis on the need to restore 'order' allowed colonial governors to label and treat opponents as criminals or as dangerous and subversive agitators firmly positioned on the wrong side of the iron curtain. Emergency regulations were rolled out and helped to create an air of legitimacy for policies of detention, curfew and censorship that were ultimately designed to maintain colonial control. To a certain extent, the emergencies would allow Britain to 'normalise' its techniques of colonial governance and to implement political and economic reforms without being constrained by normal legal checks and balances.

This is indicative of a more fundamental effect of colonial discourse, described by one authority as the "dynamic of difference", ${ }^{91}$ whereby the coloniser's world of law, state and civilisation is

\footnotetext{
${ }^{89}$ Robertson Commission, quoted in Füredi, supra note 54, at 2. See also The Robertson Commission, Report of the British Guiana Constitutional Commission (1954), presented by the Secretary of State for the Colonies to Parliament by Command of Her Majesty, September 1954.

${ }^{90}$ Füredi, supra note 54, at 160-161.

${ }^{91}$ Anghie, supra note 12 , at 267 (2005).
} 
posited against the other's negative equivalents, portrayed through the lens of backwardness: custom, tribe and savagery. The assessment by M.S. O'Rorke, the commissioner of police in Kenya, that the Mau Mau movement sprung from a "return to the savage and primitive which there is good reason to believe is the heart of the whole movement", ${ }^{92}$ is indicative. The idea of racial superiority was prevalent in the Anglo-American intellectual tradition, and was tempered only by the exposure of the consequences of Nazism. In this regard, Füredi draws our attention to a lecture given to colonial administrators in 1938 by Oxford University Professor of Anatomy Wilfrid Edward Le Gros Clark, in which he argued that although the mentality of a Kenyan boy compared favourably with that of his European counterpart, by the time he reached maturity his development was "retarded". ${ }^{93}$

Britain's primitive and backward colonial subjects were seen as driven by fear and ignorance, thus easily corrupted by the forces of evil. Looking at international law through a Third World lens that sees the discipline as integral to the 'civilising mission' of governing non-European peoples (and exploiting their territories and resources economically ${ }^{94}$ ), the invocation of emergency can be understood as an extension of that purpose. It was used as a method to contain the barbarism of the natives and to facilitate the continuance of the civilising mission. The centrality of a racial discourse to the colonial project is inescapable. In Jamaica, for example, "[o]n the pretext of crushing a dangerous rebellion, British officials had indulged in a racially charged reign of terror". ${ }^{95}$

States of emergency were thus proclaimed by Britain in Malaya in June 1948; in the Gold Coast in March 1948 and January 1950; in Kenya in October 1952; and in British Guiana in October 1953. Emergency regulations were imposed pursuant to the Emergency Powers (Colonial Defence) Order in Council of 1939, entailing wholesale powers of censorship, curfew, arrest, detention and deportation. These episodes were playing out concomitant to the drafting of the foundational charters of the fledgling international human rights system. The positions adopted by Britain during that drafting process in the late 1940s and early 1950s, therefore, cannot be viewed in isolation from events in the colonies at the time.

\footnotetext{
$9^{2}$ Quoted in Füredi, supra note 54, at 111.

${ }^{93}$ Quoted in Füredi, id., at 128.

${ }^{94}$ By 1965 Memmi had arrived at the conclusion that "[t]oday, the economic motives of colonial undertakings are revealed by every historian of colonialism. The cultural and moral mission of a colonizer, even in the beginning, is no longer tenable". See Memmi, supra note 1, at 69 .

${ }^{95}$ Kostal, supra note 38 , at 461.
} 


\section{The Emergency Derogation Provisions IN the ECHR AND ICCPR}

Extensive emergency legislation had also been introduced for the duration of the Second World War in Britain itself, where substantial numbers of people were detained by the government without charge, or trial, or term set. This was justified on the basis of national security, and the majority of those detained were refugees from Europe - defined as "enemy aliens" for the purpose of their detention. British citizens were also detained under Regulation 18B of the Defence Regulations, recourse to which was made extensively by Churchill's administration in the early years of the war. ${ }^{96}$ Later on in the war, however, Churchill himself came to feel increasingly uncomfortable with the trampling of civil liberties in Britain. In anticipating opposition to the planned release from internment of Oswald Mosley, founder of the British Union of Fascists, Churchill reminded his Home Secretary in late 1943 that detention without charge or trial "is the foundation of all totalitarian government whether Nazi or Communist". ${ }^{97}$ The post-war movement for the international protection of human rights emerged largely in response to such totalitarianism; conceived of in order to preclude the types of abuses perpetrated during the Second World War. International organisations such as the United Nations and the Council of Europe went about institutionalising mechanisms to serve that end.

However, some of the major international human rights conventions formulated over the course of the years following the war would ultimately grant States a pass to derogate from many of their newly-codified human rights obligations in the event of a self-diagnosed emergency. ${ }^{98}$ Churchill's sentiments on detention without trial appear to have been quickly forgotten. The genesis of the state of emergency/derogations clauses of two of the major human rights conventions whose drafting process Britain was involved in at the time, the European Convention on Human Rights (ECHR) and the International Covenant on Civil and Political Rights (ICCPR), will be reviewed in this section. ${ }^{99}$ What transpires is evidence of staunch British advocacy for states to reserve the discretion to deploy extraordinary measures beyond the pale of the nascent human rights system as and when they deem necessary.

\footnotetext{
${ }^{96}$ For a detailed exploration of the use of Regulation 18B, see A.W.B. Simpson, In the Highest Degree Odious: Detention without Trial in Wartime Britain (1992).

97 Telegram sent from Cairo by Prime Minister Winston Churchill to Home Secretary Herbert Morrison, 21 November 1943. Quoted in Simpson, id., at 391.

${ }^{98}$ See Article 4 of the International Covenant on Civil and Political Rights; Article 15 of the Council of Europe Convention for the Protection of Human Rights and Fundamental Freedoms (commonly referred to as the European Convention on Human Rights); Article 27 of the American Convention on Human Rights.

99 The other component of the International Bill of Rights, the International Covenant on Economic, Social and Cultural Rights (ICESCR), is not included here as it does not provide for states to derogate from its provisions in the event of a state of emergency. The rights set down in the ICESCR are subject to 'progressive realisation' according to the state's available resources. As such the obligations on states are not immediately binding, and on that basis it is likely that provision for emergency derogation was considered superfluous.
} 
This naturally raises questions as to why Britain, in the context of developing safeguards for human rights, was determined to provide for the suspension of those safeguards by virtue of emergency powers, the likes of which its wartime leader had described as the "foundation of all totalitarian government". The above discussion of Britain's historical use of martial law and emergency legislation in its overseas colonies ${ }^{100}$ and of the colonial 'emergencies' that were playing out at the time of the drafting of the conventions ${ }^{101}$ suggest that the answer relates to the preservation of control in situations where government is conducted by threat of force rather than by consent. In this regard, a statement made by the British representative during the drafting process of the ECHR regarding the importance of deploying the Convention against threats to political stability "from within or without" ${ }^{102}$ is testament to the interrelation between the newly evolving international legal mechanisms and Britain's wartime and colonial emergency powers. Another particular aspect of the legal historical context also bears noting here. The first major human rights instrument to be drawn up and adopted after the Second World War was the Universal Declaration of Human Rights. During the drafting process for that document, the question of the application of human rights to colonies-absent entirely from initial deliberations and drafts-was raised in 1947 by the Soviet Union, the self-proclaimed leader of the world's "anti-imperialist camp" ${ }^{103}$ After that, "the British and Soviet delegations clashed more than once over the implications of the Declaration for the peoples living in the colonies". ${ }^{104}$ Britain repeatedly moved to have the proposed article affirming the application of the Declaration to Non-Self-Governing-Territories (which includes colonial territories) deleted. This would have been inconsistent with the UN Charter and the principles of non-discrimination and self-determination, and thus while the British eventually succeeded in having the 'application to the colonies' provision demoted from its own separate article, it was decided to explicitly confirm, by virtue of the Preamble and as a part of Article 2, that the Declaration would apply to the colonies. ${ }^{105}$ Thus a declaratory principle of the applicability of human rights law to all territories, including colonies, under a state's jurisdiction was established. As a result, Britain entered the drafting process for the relevant legally binding human rights instruments

\footnotetext{
${ }^{100}$ Section II, supra.

${ }^{101}$ Section III, supra.

${ }^{102}$ See Council of Europe, Collected Edition of the Travaux Préparatoires of the European Convention on Human Rights Vol. I $30(1975-1985)$.

${ }^{103}$ Andrei Zhadanov, then chairman of the Soviet of the Union, quoted in Johannes Morsink, The Universal Declaration of Human Rights: Origins, Drafting, and Intent 97 (1999).

${ }^{104}$ Morsink, id., at 97.

${ }^{105}$ For a concise overview of the debate on this issue, see Morsink, id., at 96-101.
} 
wary of the need to retain the necessary latitude to deal with the 'emergencies' it was facing in certain parts of the empire. ${ }^{106}$

\section{A. Article 15, European Convention on Human Rights}

As far as international conventions go, the drafting process of the European Convention on Human Rights was relatively swift. Stemming from an initiative of the Consultative Assembly of the newly-formed Council of Europe during its August-September 1949 sitting, the Committee of Ministers worked through a number of alternative drafts proposed by an intergovernmental 'Committee of Experts' formed in early 1950. The Committee of Ministers adopted the text of a "draft Convention for the Protection of Human Rights and Fundamental Freedoms" in Strasbourg in August of that year; the Convention was signed in Rome by November 1950, entering into force in September $1953 .{ }^{107}$

The starting point for the Convention was a draft text included in a recommendation adopted in September 1949 by the Consultative Assembly of the Council of Europe on "measures for the fulfilment of the declared aim of the Council of Europe, in accordance with Article 1 of the Statute in regard to the safeguarding and further relation of human rights and fundamental freedoms ${ }^{\prime \prime}{ }^{108}$ This, the first working draft of the European Convention, contained no reference to, or provision for, derogation from human rights safeguards in time of emergency. It did, however, contain in draft Article 6 a general limitation clause that echoed Article 29(2) of the Universal Declaration of Human Rights. ${ }^{109}$

\footnotetext{
${ }^{106}$ Although in the case of the ECHR Article 63 would ultimately be framed so as to waive the automatic application of the Convention to non-metropolitan territories, by that stage the inclusion of the emergency derogation clause had been secured. The European powers would thus be able to extend the Convention to their colonial territories while falling back on the option of derogation under Article 15 whenever necessary. This was the tack that Britain would take, while France, on the other hand-where the discrimination that was effectively allowed for by Article 63 was met with vehement opposition from the elected representatives of the French colonial territories-chose not to ratify the Convention until 1974, long after most of its colonies had achieved independence, and with a reservation to Article 15 at that. See 27 Yearbook of the European Convention on Human Rights 4 (1974).

${ }^{107}$ The fullest available account of the drafting process and reproduction of published documents can be found in Council of Europe, supra note 102.

${ }^{108}$ See European Commission of Human Rights, Preparatory Work on Article 15 of the European Convention on Human Rights, Council of Europe Doc. DH (56) 4, para. 2, p. 2 (22 May 1956).

${ }^{109}$ Council of Europe Doc. AS (1) 108, p. 262. It appears that general limitations established by law for the purpose of public order and security were considered sufficient to deal with exceptional circumstances. When the possible need to explicitly authorise state signatories to the proposed Convention to take "special measures" to deal with incitement to violence, the Committee on Legal and Administrative Questions determined this to be unnecessary, as such situations were already covered by the text of draft Article 6. See Council of Europe Doc. AS (1) 77, para. 16, p. 201.
} 
The records of the Consultative Assembly's first session provide an early indication of Britain's position that the purpose of enacting a human rights convention was not only the protection of individuals, but that its central functions would also include the strengthening of governments' legal armoury in suppressing opposition to their rule. The British representative, Lord Layton, stressed to the Assembly the importance of operationalising the convention "as a means of strengthening the resistance in all our countries against insidious attempts to undermine our democratic way of life from within or without, and thus to give to Western Europe as a whole greater political stability". ${ }^{110}$

It was perhaps with this in mind that the UK sought to introduce a provision at the meetings of the Committee of Experts from 2-8 February 1950 allowing for derogation from the majority of the rights enumerated in the Convention during times of public emergency. In advance of those meetings, the Secretariat-General had drawn up a 'preparatory report on a preliminary draft convention for the collective guarantee of Human Rights'. Part of that report was devoted to a comparison between the draft International Covenant on Human Rights in progress at the time, and the draft European Convention as recommended by the Consultative Assembly. In relation to the state of emergency/derogation provision being mooted for the International Covenant, the report found that "the inclusion of this provision in the European system appears to be unnecessary", having regard to the existing limitation clauses in the Consultative Assembly's draft. ${ }^{111}$ Despite this, on 4 February 1950, Sir Oscar Dowson submitted to the Committee of Experts on behalf of the UK an amendment to the Consultative Assembly draft to include an article allowing states to derogate from their obligations in "time of war or other public emergency threatening the interests of the people" ${ }^{112}$

Such a right of derogation in exceptional circumstances was still deemed by other states to be superfluous to the requirements and aims of the Convention, and the preliminary draft Convention developed by the Committee of Experts during its February 1950 session contained no such clause. ${ }^{113}$

Britain retained an unyielding position, however, and at the second session of the Committee of Experts from 6-10 March tabled a new amendment, with some clarifications but the same

\footnotetext{
${ }^{110}$ Report of the Consultative Assembly, First Session, Part I, Fifth Sitting (16 August 1949), p. 83-85; quoted in Council of Europe, supra note 102, Vol. I, at 30 .

${ }^{111}$ Council of Europe Doc. B 22, p. 18.

${ }^{112}$ See Report of the Meetings of the Committee of Experts, sitting of 4 February 1950, Council of Europe Doc. A 782.

${ }^{113}$ Preliminary Draft Convention for the Maintenance and Further Realisation of Human Rights and Fundamental Freedoms, Council of Europe Doc. A 833, 15 February 1950. This draft retained, with slightly different wording, the Article 6 general limitation clause of the original Consultative Assembly draft of September 1949.
} 
general thrust as its previous proposed amendment. ${ }^{114}$ Following lengthy discussion on a number of contentious issues, the Committee of Experts decided to submit alternative texts to the Committee of Ministers without indicating a preference. On its proposed amendment regarding emergency derogations, Britain was insistent. Having successfully secured its inclusion in the first set of alternatives, the British representative rallied for it to also be included in the second set. In response, the French and Italian representatives stated that they were opposed to its insertion in the text of alternatives $A$ and $A / 2$. They considered that this provision was contrary to the system of these alternatives, since it provides detailed regulations concerning the kind of cases already covered by the general provisions of Articles 6,7 and $10 .{ }^{115}$ Ultimately, other members of the Committee came down on the British side, on the basis of a belief that the procedure laid down in the derogation clause "could prove to be useful for the protection of Human Rights in exceptional circumstances". ${ }^{116}$ Thus, both sets of alternative drafts annexed to the Committee of Expert's Report to the Committee of Ministers contained similar emergency derogation provisions. ${ }^{117}$ Notably, that report draws attention to the importance attached by Britain to the imposition of clearly defined limitations on the rights enumerated in the Convention. While noting that all members of the Committee were in favour of drawing up a Convention aimed foremost at safeguarding human rights, the report observes that:

Certain members, however - particularly the representatives of the United Kingdom and the Netherlands - considered that the fundamental rights to be safeguarded, and, even more important, the limitations of these rights, should be defined in this Convention in as detailed as manner as possible. ${ }^{118}$

A reading of the travaux préparatoires of the European Convention suggests throughout that the British interest was concerned with the limitations on the rights prescribed in the Convention as much as, if not more than, the rights themselves.

With the derogations clause incorporated into both sets of alternatives proposed by the Committee of Experts, its inclusion in the final text of the Convention was all but secured. The British derogation provision was included in June 1950 draft Convention, ${ }^{119}$ and remained

\footnotetext{
${ }^{114}$ See Council of Europe Doc. CM/WP 1 (50) 2, pp. 1-2.

${ }^{115}$ Council of Europe Doc. CM/WP 1 (50) 15, p. 20.

${ }^{116} / d$.

${ }^{117}$ Council of Europe Doc. CM/WP 1 (50) 15 Appendix, alternatives A and A/2, p. 4; alternatives B and B/2, p. 5-6.

${ }^{118}$ Council of Europe Doc. CM/WP 1 (50) 15; A 924, 16 March 1950, reproduced in Council of Europe, supra note 102, Vol. IV, at 8.

${ }^{119}$ Council of Europe Doc. CM/WP 4 (50) 16, Appendix; A 1445.
} 
unchanged in subsequent drafts, save for one significant change: the term "the interests of the people" was replaced with "the life of the nation". ${ }^{120}$ No explanation for this last minute amendment is given in the report of the Conference Senior Officials; all that can be surmised is that an intervention was made in order to relate emergencies justifying derogation more to national, or state, interests, and less to the interests of the population or its individuals. The same issue of terminology would also arise in relation to Article 4 of the ICCPR, and is discussed further in part ii of this section.

The emergency derogation provision was adopted, without any special reference to it in the course of the Consultative Assembly's debate, ${ }^{121}$ as Article 15 of the Convention for the Protection of Human Rights and Fundamental Freedoms, signed on 4 November 1950. The final text of Article 15 reads as follows:

1. In time of war or other public emergency threatening the life of the nation any High Contracting Party may take measures derogating from its obligations under this Convention to the extent strictly required by the exigencies of the situation, provided that such measures are not inconsistent with its other obligations under international law.

2. No derogation from Article 2, except in respect of deaths resulting from lawful acts of war, or from Articles 3, 4 (paragraph 1 ) and 7 shall be made under this provision. ${ }^{122}$

3. Any High Contracting Party availing itself of this right of derogation shall keep the Secretary-General of the Council of Europe fully informed of the measures which it has taken and the reasons therefor. It shall also inform the Secretary-General of the Council of Europe when such measures have ceased to operate and the provisions of the Convention are again being fully executed.

The individual limitation clauses for specific rights, that had been proposed originally as an alternative to full powers of derogation, were also included in the Convention. ${ }^{123}$

\footnotetext{
${ }^{120}$ Council of Europe Doc. CM/WP 4 (50) 19 annexe; CM/WP 4 (50) 16 rev.; A 1452.

${ }^{121}$ Council of Europe Doc. AS (2) 104, p. 1035.

${ }^{122}$ Article 2 relates to the right to life; Article 3 to the right to freedom from torture and inhuman or degrading treatment or punishment; Article 4(1) to freedom from slavery and servitude; Article 7 to the non-retroactivity of criminal law.

${ }^{123}$ See Articles 8-11.
} 


\section{B. Article 4, International Covenant on Civil and Political Rights}

The European Commission of Human Rights noted in 1956 that "[a]s the preparatory work clearly shows, Article 15 of the European Convention of Human Rights closely followed, at the beginning, that of Article 4 of the United Nations draft Covenant". ${ }^{124}$ Indeed, at its initial introduction, the British proposed amendment to the draft European Convention "appeared to be an almost textual reproduction"125 of draft Article 4 of the Covenant.

The process that would lead to adoption of the ICCPR began with the Drafting Committee of UN Commission on Human Rights in 1947, mandated to prepare an international bill of human rights. ${ }^{126}$ The proposal for an emergency clause came from a draft international bill of human rights submitted by Britain to the first session of the Drafting Committee. The Drafting Committee also had before it a number of draft outlines of an international bill of human rights prepared by the Division of Human Rights of the Secretariat, the United States of America and France, none of which made any provision for derogation or emergency measures. ${ }^{127}$ Article 4 of the British draft, on the other hand, stipulated that "[i]n time of war or other national emergency, a State may take measures derogating from its obligations under Article 2 above to the extent strictly limited by the exigencies of the situation" ${ }^{128}$ The sweeping nature of this proposed right of derogation is brought into sharp focus by the fact that Article 2 of Britain's draft Bill provided for states' obligations to secure and support all of the human rights and fundamental freedoms set out in the Bill, as well as to provide effective remedy in cases of violation. The proposal therefore left every right enumerated exposed to derogation in times of emergency, allowing no exceptions in favour of non-derogable rights. It was passed on by the Drafting Committee to the Commission on Human Rights, where the proposed article was rejected by a vote at the Commission's second session in December $1947 .{ }^{129}$

\footnotetext{
${ }^{124}$ European Commission of Human Rights, supra note 108, para. 15, p. 10.

${ }^{125} / d$., para. 7, p. 5.

${ }^{126}$ The International Bill of Human Rights would ultimately take the form of three documents: the Universal Declaration on Human Rights, adopted by the UN General Assembly in 1948, and two international treaties - the International Covenant on Civil and Political Rights, and the International Covenant on Economic, Social and Cultural Rights - both of which were adopted by the UN in 1966 and entered into force in 1976.

${ }^{127}$ See Report of the Drafting Committee to the Commission on Human Rights, UN Doc. E/CN.4/21, annexes A, C, and D respectively.

${ }^{128}$ British Foreign Office, United Kingdom Draft of an International Bill of Human Rights (1947), Appendix 2, p. 8. Reproduced in UN Doc. E/CN.4/21, annex B.

${ }^{129}$ UN Doc. E/CN.4/AC.3/SR.8, p. 11.
} 
Britain resubmitted an almost identical draft provision in the Commission ${ }^{130}$ and this time successfully lobbied for its inclusion in the draft covenant. ${ }^{131}$ This draft derogation clause thus went back to the Drafting Committee, where it was criticised by a number of states, the United States being the most vocal among them. ${ }^{132}$ Following the adoption of a number of special limitation clauses in relation to particular rights, the US moved to strike the entire derogation clause on the basis that it was rendered superfluous by the limitation clauses. ${ }^{133}$ France proposed a compromise text, which amounted to a general limitation clause that would not apply to a wide range of non-limitable rights. ${ }^{134}$ Britain maintained its unwavering position favouring derogation over limitation, however, and revised the French draft into a derogation clause with a narrower range of non-derogable rights. ${ }^{135}$ This was the version of Article 4 that was provisionally adopted by the Commission on Human Rights at its fifth session in June 1949. ${ }^{136}$

From that point onward, the British revision formed the basis for further tinkering with the wording of Article 4, but despite continuing opposition from some quarters, the fundamental premise of the right of states to derogate during emergencies was not to be dislodged from the covenant. ${ }^{137}$ Interestingly, however, the travaux préparatoires do provide evidence that the risk that Britain's proposal to permit human rights to be abrogated during emergencies "might produce complicated problems of interpretation and give rise to considerable abuse" 138 was foreseen at the time. Britain persuaded enough members of the Commission that it was necessary to envisage possible conditions of emergency when derogations from the law of human rights "would become essential". ${ }^{139}$ Somewhat ironically, "reference was made to the history of the past epoch during which emergency powers had been invoked to suppress

\footnotetext{
${ }^{130}$ See UN Doc. E/CN.4/SR.423, p. 4 .

${ }^{131}$ The proposal was accepted by four votes to three with eight abstentions. UN Doc. E/CN.4/SR.431, p. 5.

${ }^{132}$ US opposition was based principally on the belief that a single, general limitation clause in the vein of Article 29(2) of the Universal Declaration of Human Rights was sufficient, and preferable. The US representative submitted an alternative text accordingly. See UN Doc. E/80o.

${ }^{133}$ See UN Docs. E/CN.4/AC.1/SR.22; E/CN.4/SR.127; E/CN.4/170.Add.1.

${ }^{134}$ UN Doc. E/CN.4/187.

${ }^{135}$ UN Doc. E/CN.4/188.

${ }^{136}$ See UN Docs. E/CN.4/187; E/1371, Article 4.

${ }^{137}$ A Chilean proposal to delete Article 4 was rejected at the sixth session of the Commission on Human Rights in 1950 . UN Doc. E/CN.4/SR.195.

${ }^{138}$ Annotations on the text of the draft International Covenants on Human Rights, prepared by the UN Secretary-General, UN Doc. A/2929, 1 July 1955, Chap. V, para. 36.

${ }^{139}$ Id., Chap. V, para. 37.
} 
human rights and to set up dictatorial regimes" ${ }^{140}$ in support of the position that the use of emergency powers should be formally authorised and monitored, rather than precluded.

Throughout the 1950s and early 1960s, as the drafting process continued, debates cropped up in respect of various aspects of the wording of Article 4. Worth noting is the discussion on whether, in order for derogation to be justified, the "public emergency" referred to in the article must pose a threat to "the interests of the people" or "the life of the nation". On this,

It was thought that the reference to a public emergency 'which threatens the life of the nation' would avoid any doubt as to whether the intention was to refer to all or some of the people, although it was suggested that a reference to 'the interests of the people' was more appropriate in a covenant which dealt with the rights of individuals and that such a phrase would also prohibit Governments from acting contrary to the interests and welfare of their people. ${ }^{141}$

Again it was Britain that took the lead, replacing existing proposals that spoke of "public emergency gravely threatening the interests of the people ${ }^{\prime 142}$ with a revision that related to "public emergency threatening the life of the nation"143 that was adopted at the eight session of the Commission on Human Rights in 1952. ${ }^{144}$ This would remain unaltered in the Article 4 of the instrument that would ultimately be adopted as the International Covenant on Civil and Political Rights in 1966.

\section{Derogations in Practice}

The major wave of decolonisation that surged through the Third World was to peak during the 1950s and early 1960s, while the ICCPR was still in gestation but by which time the ECHR was very much alive and kicking. The contention that the inclusion of the emergency derogation provision in the Convention would allow Britain to cast a light of lawfulness on policies that were becoming increasingly repressive, as the knots binding the empire began to unravel, was borne out by practice in the early years of the ECHR's application.

\footnotetext{
${ }^{140}$ Id., Chap. V, para. 38.

${ }^{141}$ Id., Chap. V, para. 40.

${ }^{142}$ Proposals in UN Docs. E/CN.4/365 and E/CN.4/498.

${ }^{143}$ See UN Docs. E/CN.4/L.139 and E/CN.4/L.139/Rev.1.

${ }^{144}$ UN Doc. E/CN.4/SR.331, p. 5.
} 
In the decade following the entry into force of the ECHR, Britain availed of its right to derogate on numerous occasions, not in mainland Britain, but in various colonial contexts. The Convention came into force in September 1953. Within the first year of its application, the British government submitted a notification of derogation pursuant to extant emergencies in Kenya, Uganda, the Federation of Malaya, the Colony of Singapore, and British Guiana. ${ }^{145}$ In the subsequent years Britain invoked Article 15 of the Convention to derogate from obligations in Cyprus, ${ }^{146}$ the Protectorate of Northern Rhodesia, ${ }^{147}$ the Protectorate of Nyasaland, ${ }^{148}$ the Colony of Aden, ${ }^{149}$ the Zanzibar Protectorate ${ }^{150}$ and Mauritius. ${ }^{151}$ It also notified the Council of Europe of further derogations in respect of Kenya ${ }^{152}$ and Singapore. ${ }^{153}$

For perspective, if Turkey ${ }^{154}$ is taken out of the equation, this batch of derogations by Britain in eleven different colonial situations in a decade amounts to more derogations than have been made by the Council of Europe's other 45 member states combined in more than fifty years of the Convention's application. ${ }^{155}$ Britain's resort to emergency powers, however, ultimately proved incapable of deflecting the "wind of change"156 that was blowing through Africa and, indeed, much of the empire by the start of 1960s. The derogations that had not been revoked

\footnotetext{
${ }^{145}$ Note verbale of 24 May 1954, 1 Yearbook of the European Convention on Human Rights 48-49 (1958).

${ }^{146}$ Note verbale of 7 October 1955, 1 Yearbook of the European Convention on Human Rights 49 (1958); Note verbale of 13 April 1956, 1 Yearbook of the European Convention on Human Rights 49-50 (1958); Note verbale of 21 January 1959, 2 Yearbook of the European Convention on Human Rights 78 (1959). It is worth noting that the emergencies mentioned in this section generally entailed special powers of detention, and in some cases deportation, but it was only with regard to Cyprus that Britain's notification expressly indicated derogation from Article 5 of the Convention pertaining to the right to liberty and security of person.

${ }^{147}$ Note verbale of 16 August 1957, 1 Yearbook of the European Convention on Human Rights 51 (1958).

${ }^{148}$ Note verbale of 25 May 1959, 2 Yearbook of the European Convention on Human Rights 84 (1959); Note verbale of 11 January 1961, 4 Yearbook of the European Convention on Human Rights 39 (1961).

${ }^{149}$ Note verbale of 7 January 1960, 3 Yearbook of the European Convention on Human Rights 68 (1960).

${ }^{150}$ Note verbale of 5 December 1961, 4 Yearbook of the European Convention on Human Rights 44 (1961).

${ }^{151}$ Undated notice in 8 Yearbook of the European Convention on Human Rights 14-17 (1965).

${ }^{152}$ Note verbale of 21 September 1960, 3 Yearbook of the European Convention on Human Rights 48 (1960).

${ }^{153}$ Note verbale of 11 May 1960, 3 Yearbook of the European Convention on Human Rights 75 (1960).

${ }^{154}$ Turkey has derogated under Article 15 several times, including in 1963, 1974, 1978, 1979, 1980, and 1990. A number of these derogations relate to the situation in Cyprus.

${ }^{155}$ Derogations include those made by Greece (1967); Ireland (1957, 1976); France (1985, in respect of New Caledonia); Albania (1997); Armenia (2008)

${ }^{156}$ Speech of British Prime Minister, Harold MacMillan to the Parliament of South Africa, 3 February 1960. For analysis see Frank Myers, Harold Macmillan's "Winds of Change" Speech: A Case Study in the Rhetoric of Policy Change, 3:4 Rhetoric \& Public Affairs 555 (2000).
} 
by the time the territories concerned acquired independence lapsed upon such acquisition. Widespread decolonisation was held up as the decisive banner in support of the powerful claim that international law had finally become truly universal.

In one of the colonial conflicts that remained, however, Britain continued to rely on emergency as a tool of domination. Northern Ireland was subjected to derogation from June $1957^{157}$ until August $1984,{ }^{158}$ with special powers of detention, search and seizure, and censorship reserved by Britain. After a temporary lapse, Britain invoked its right to derogate again; this emergency would last from 1988 until 2001. ${ }^{159}$ These declarations of what ended up as entrenched emergencies were supported by a steady spate of statutes-Emergency Powers Acts and Prevention of Terrorism Acts. These acts made further legislative allowance for the state of emergency that had effectively been in place in the north of Ireland since the enactment of the Civil Authorities (Special Powers) Act (Northern Ireland) of 1922, which remained in place until the enactment of the Northern Ireland (Emergency Provisions) Act of 1973. The emergency powers were expanded into mainland Britain starting with the Prevention of Terrorism (Temporary Provisions) Act of 1974, which introduced new powers to exclude from Great Britain persons suspected of involvement in terrorism associated with Northern Ireland, and provided the police with powers to arrest and detain suspects without warrant for up to a total of seven days. ${ }^{160}$ The presentation of the threat to security in the Northern Irish context was not dissimilar to that which had underpinned Britain's discourse of emergency in Kenya, Malaya, and elsewhere.

Britain's emergency laws and derogations have come under the judicial microscope of the European Court of Human Rights numerous times. One chain of events in this regard is particularly telling. The case of Brogan ${ }^{161}$ related to emergency powers promulgated under the Prevention of Terrorism Act of 1984 that allowed persons suspected to have been involved in acts of terrorism to be detained for seven days without charge and without being brought before a judge. The Court found such measures to constitute a violation of Article 5 of the Convention. As noted above, Britain's long-standing derogation to the Convention had been

\footnotetext{
${ }^{157}$ See letter of 27 June 1957, 1 Yearbook of the European Convention on Human Rights 50 (1958).

${ }^{158}$ Council of Europe, Information Bulletin on Legal Activities Within the Council of Europe and in Member States, vol. 21, p.2 (1985).

${ }^{159}$ Note verbal of 23 December 1988, 31 Yearbook of the European Convention on Human Rights 15-16 (1988); Letter from the Permanent Representative of the United Kingdom to the Secretary-General of the Council of Europe, 19 February 2001.

160 The Prevention of Terrorism (Temporary Provisions) Act 1974, $\$ 7(1)$ allowed police to detain individuals on their own authority for forty-eight hours, while $\$ 7(2)$ provided for an extension of detention for a further period of up to five days authorised by the Secretary of State. This 1974 Act was augmented and expanded upon by the Prevention of Terrorism (Temporary Provisions) Acts of 1976, 1984, and 1989.

${ }^{161}$ Brogan \& Others v. the United Kingdom, no. 11209/84; 11234/84; 11266/84; 11386/85, ECHR judgment 29 November 1988.
} 
withdrawn in 1984. The Court's decision in Brogan "undoubtedly came as a surprise to the British government, and it quickly had to decide how to react". ${ }^{162}$ The response was not to revoke the special powers of detention, but rather to immediately lodge a new derogation under Article 15 in order to exempt the seven-day executive detention power from compliance with the Convention. ${ }^{163}$ Britain's argument in this regard was that it had believed itself to be operating within the boundaries of Article 5, and that when the contrary was established by the Court, derogation was reverted to. In response to a subsequent petition that challenged the validity of the new derogation, the Court came down on Britain's side. This decision in Brannigan \& McBride v. UK ${ }^{164}$ was seen by commentators as confirmation of "an exceptionally undemanding standard of review by the organs where derogations are concerned". 165

The decision was, however, not inconsistent with the European Court's own earlier jurisprudence on the matter. In the 1970s the Irish government brought an inter-state application challenging the legality of Britain's policies and practices of internment, detention and interrogation in the north of Ireland between 1971 and 1975. The British defence relied on the derogation that had been in place as justification for the practices. Regarding Article 5, on the right to liberty, the Court found that while the measures of extrajudicial deprivation of liberty were not in conformity with the Convention, they were required by 'exigencies of the situation' and thus that the derogation under which they were effected was permissible. ${ }^{166}$ The decision asserted the granting of a "wide margin of appreciation" to states in the context of Article 15, both in relation to the existence of an emergency in the first place, and the appropriate measures to be taken in deviation from the Convention:

It falls in the first place to each Contracting State, with its responsibility for "the life of [its] nation", to determine whether that life is threatened by a "public emergency" and, if so, how far it is necessary to go in attempting to overcome the emergency. By reason of their direct and continuous contact with the pressing needs of the moment, the national authorities are in principle in a better position than the international judge to decide both on the presence of such an emergency and on the nature and scope of derogations necessary to avert it. ${ }^{167}$

\footnotetext{
${ }^{162}$ Brice Dickson, The Detention of Suspected Terrorists in Northern Ireland and Great Britain, 43 Univ. Richmond L. Rev 927,948 (2009).

${ }^{163}$ Note verbal of 23 December 1988, supra note 159.

${ }^{164}$ Brannigan \& McBride v. the United Kingdom, no. 14553/89; 14554/89, ECHR judgment 25 May 1993.

${ }^{165}$ Susan Marks, Civil Liberties at the Margin: the UK Derogation and the European Court of Human Rights, 15 Oxford J. Legal Studies 69, 70 (1995).

${ }^{166}$ Ireland v. the United Kingdom, no. 5310/71, judgment 18 January 1978, at para. 243.

${ }^{167}$ Id., at para. 207.
} 
In a situation of colonialism or hegemonic control, the benefits afforded to states by this reasoning are palpable. The notion of a code of emergency legislation had thus found its way back full circle to its island of origin via extension to distant corners of the British empire and effective endorsement from the European Court of Human Rights. In terms of the extent of recourse to derogation, and the wide margin of appreciation afforded it in this respect by the Court, it appears that Britain, the driving force behind Article 15 of the ECHR, may have benefitted most from its inclusion in the Convention.

Stemming from the colonial experience, a tendency to rely on emergency derogations was etched into the British mindset from the inception of the international human rights system. The influence of that tendency persists today, and bears noting. As a direct consequence of the attacks of $11^{\text {th }}$ September 2001 in the United States, the British government chose to derogate from certain provisions of the ECHR. ${ }^{168}$ The fact that France, Germany, Italy and other European states subject to a similar general increased risk of terrorist activity did not issue derogations from the Convention has been highlighted, including by the Committee of Privy Counsellors established pursuant to Britain's Anti-terrorism, Crime and Security Act of 2001. ${ }^{169}$

\section{Reflections on the Doctrine of Emergency in Its Colonial Shadow}

In eventually accepting Britain's arguments for the inclusion of an emergency derogation clause in the European Convention on Human Rights, the majority of the other members of the Council of Europe reasoned that "it had the advantage of excluding, even in the case of war or threat to the life of the nation, any derogation of certain fundamental rights, and because the procedure laid down in paragraph 3 could prove to be useful for the protection of Human Rights in exceptional circumstances". ${ }^{170}$ This depiction presents the provision in its positive light in that certain rights are excluded from derogation and some form of accountability is entailed by virtue of the procedure to be followed when emergency powers are introduced. The less rosy perspective-that the institutionalisation of a framework under which derogations can take place during a self-proclaimed emergency may serve to cast a light of legitimacy on emergency powers themselves-foreseen though it may have been during the drafting process, was in the end reduced to second fiddle. Questions beg as to what extent this was due to a well-intended, but in retrospect somewhat naïve, expectation on behalf of the drafters as to

\footnotetext{
${ }^{168}$ Human Rights Act 1998 (Designated Derogation) Order 2001 (SI 2001/3644).

${ }^{169}$ Anti-terrorism, Crime and Security Act 2001 Review: Report, HC 100, 18 December 2003, para. 189.

${ }^{170}$ Council of Europe Doc. CM/WP 1 (50) 15, p. 20.
} 
how states would henceforth conduct themselves in exceptional circumstances; and, conversely, to what extent it was due to the realities of the enduring intrinsic structures of international law, whereby states will ultimately legislate with their own interests primarily accounted for.

The doctrine of emergency remains prone today to exploitation by regimes inclined to repress opposition and dissent. As such, the merits of bestowing universal applicability upon a paradigm derived from a distinctly colonial context can be appraised on a number of levels.

\section{A. TEMPORALITY AND THE LANGUAGE OF EMERGENCY}

The term 'emergency' is synonymous with a sudden and unexpected event, typically potentially disastrous in its consequences and requiring a swift and urgent response that is not afforded the luxury of planning. While the architects of the emergency derogation clauses in human rights treaties may argue that it is a similarly narrow notion, in theory, which they intended to legislate for, the concept of 'emergency' has been given a much broader construction in practice. The idea of a prolonged or indefinite emergency evolved as the armoury of emergency legislation on Britain's statute books to deal with threats and disturbances in the overseas empire steadily expanded throughout the nineteenth century, to the point that territories such as Ireland and India were in states of emergency more often than they were in states of 'normalcy'. 'Normalcy', for its part, is defined by the predominance of the norm, the general rule, the habitual state of affairs that prevails most frequently. This understanding of 'normalcy' was turned on its head somewhat by the entrenchment of quasi-permanent emergencies that veered towards "a new conception of normality that takes vastly extended controls for granted, and thinks of freedom in smaller and smaller dimensions". ${ }^{171}$ We have seen how Ireland was effectively governed by emergency rule for over a century before independence, an approach that continued in Northern Ireland, post-partition. In spite of evidence of this 'new conception', emergency derogations were indoctrinated in various international human rights conventions, and the idea of temporal limitations on the discretion of the state to proclaim an emergency has been exposed as a fallacy. Today's 'permanent' states of emergency around the world, most notably in North Africa (Algeria, Egypt) and the Middle-East (Israel, Syria) display no indication of coming to a close. In such instances, the nomenclature of 'emergency' and 'normalcy' is rendered meaningless.

The language of human rights law itself in the context of states of emergency is also reflective of the colonial origins of the doctrine. Pursuant to the extant emergency legislative system, the

\footnotetext{
${ }^{171}$ Harold D. Lasswell, National Security and Individual Freedom 29 (1950).
} 
British executive would typically authorise repressive measures against "any person who is suspected of acting or having acted or of being about to act in any manner prejudicial to the public safety or the defence of the Realm". ${ }^{172}$ That threat to the defence of the imperial 'Realm' finds parallel in the threat to the 'life of the nation' that triggers the right of states to derogate from their human rights law obligations. In the colonial 'emergencies' that formed the backdrop for the assumption of special powers, the threat in question was invariably to the metropole's national or governmental interest in the colony, rather than to the interest of the people of the colony or even the people of the metropole itself. Thus the Defence of India Act of 1915, for example, allowed the Governor-General to make regulations for securing "the public safety and defence of British India". ${ }^{173}$ The language of the Emergency Powers (Colonial Defence) Order in Council of 1939-which was invoked as the basis for emergency regulations throughout the empire not just during the Second World War but also subsequent to it-entails similar allusions to Britain's ambitions of retaining territorial control of its colonies:

the Governor may make such regulations as appear to him to be necessary or expedient for securing the public safety, the defence of the territory, the maintenance of public order and the suppression of mutiny, rebellion and riot. ${ }^{174}$

The not insignificant amendments made to the drafts of both the ECHR and ICCPR to allow for derogation in the case of a threat to 'the life of the nation' rather than a threat to 'the interests of the people' as per the original text is discussed in section IV, above. It bears reiterating that this statist-leaning adjustment was made at Britain's behest in spite of contentions made during the drafting process "that a reference to 'the interests of the people' was more appropriate in a covenant which dealt with the rights of individuals and that such a phrase would also prohibit Governments from acting contrary to the interests and welfare of their people". ${ }^{175}$

\section{B. The Space Between: Spatial aspects of the Normalcy-Emergency Divide}

We have seen how resort to martial law in mainland Britain was effectively abolished by the Petition of Right in 1628, while its use was continued and even expanded in the empire overseas. In the nineteenth century, Britain enjoyed relative stability in both the political and socio-economic sense and had become increasingly governable within the ordinary course of

\footnotetext{
${ }^{172}$ This example is taken from a regulation promulgated in Ireland in 1918 pursuant to the Defence of the Realm Act. See Colm Campbell, Emergency Law in Ireland, 1918-1925 104 (1994).

${ }^{173}$ Emphasis added.

${ }^{174}$ Section 6(1), Emergency Powers Order in Council, 1939.

${ }^{175}$ Annotations on the text of the draft International Covenants on Human Rights, supra note 138, Chap. V, para. 40.
} 
the law. Across the water, Ireland, by contrast, was in a state of political discontent and economic turmoil. Civil disobedience was provoked by discriminatory religious laws and taxes, while the country's predominantly agrarian population was strangled by British land policies and exploitation of resources, resulting in mass starvation and emigration. It was in this context that the array of colonial emergency legislation was enacted in Ireland.

The reliance on martial law and emergency codes to maintain control in the colonies, while a 'normal' legal regime was maintained in mainland Britain, exemplifies a dichotomy of diverging legal regimes operating contemporaneously but independently in two spaces within a single 'control system'. As such it can be understood as the antecedent of the spatial distinction that is often perceived as separating situations of emergency and normalcy. In such situations, "the claim is that the two realities and the two concomitant legal regimes - that of emergency applicable to the dependent territory and that of normalcy applicable to the controlling territory - are maintained separately and do not affect each other." ${ }^{176}$ However, such a claim of absolute separation is untenable and "misguided", ${ }^{177}$ geographic boundaries are often permeable when emergency powers are concerned. The examples of the World Wars are indicative, whereby emergency measures employed by the British army abroad did find their way onto the statute books governing mainland Britain. It might be argued that this was a mere temporary blip necessitated by the truly exceptional circumstances of the major wars, that normalcy was subsequently restored in Britain, and that engagement with the international human rights treaties consolidated the rule of law and human rights. However, experience has demonstrated otherwise. Britain's influence ensured the human rights treaties were crafted in such a way so as not to unduly hamper the administration of the colonies, which had come to rely heavily on the use of emergency powers. The facility to derogate from such treaties was availed of initially only in the colonies, but invariably spilled back over again. Britain derogated from the ECHR in Northern Ireland in 1957 on account of the emergency powers it had invoked there. Derogation on the basis of the Irish threat subsequently encompassed mainland Britain, to which derogation has also applied in the more recent context of the transnational 'war against terrorism'.

On this basis, the space that is created between normalcy and emergency along territorial boundary lines appears as an artificial construction, ungrounded in reality. Such a division may have been tenable in the 1800s when martial law was commonplace in its application from Canada to the Caribbean and South Africa to Sri Lanka, but precluded from the domestic legal system at home in Britain. Spatial distinctions between norm (metropole) and exception (colony) are much more blurred in the modern context, even in situations that may be

\footnotetext{
${ }^{176}$ Gross \& Ní Aoláin, supra note 9, at 181.

${ }^{177}$ /d.
} 
characterised as colonial in nature, such as that of Israel and the Palestinian territories, or Britain and the north of Ireland. This blurring of the lines highlights the incongruity of international human rights law incorporating a provision for universal application into its doctrinal corpus that was heavily influenced by the specific political and historical context of colonial governance.

The relation between the state of emergency and international humanitarian law also warrants mention. The origins of humanitarian law can be traced to the 1859 Battle of Solferino, "a very European battle", with its norms at that time designed exclusively for European enjoyment. ${ }^{178}$ There was no incentive for European states to limit the scope of military campaigns outside of Europe, with non-European peoples and their territories having been stripped of any legal personality upon subjection to colonial domination. ${ }^{179}$ Thus the European powers did not consider their forces constrained in the pursuit of imperial conquest, nor in their use of martial law in the colonies, even after the inception of international humanitarian law. By the time that the push to dismantle the colonial empires had gained irreversible momentum in the 1950s, international humanitarian law was still not a factor in the protection of the rights of the 'natives'.

In contemporary situations where a state of emergency occurs in the context of an armed conflict or belligerent occupation, the tendency of states to exploit the vulnerability of human rights law by the invocation of the doctrine of emergency has recently been accompanied by parallel attempts to undermine the relevance of humanitarian law on the basis that it is insufficient to deal with 'exceptional' or 'asymmetrical' threats faced by the given state. The state of exception narrative that has sought to establish legal 'black holes' in the context of the war against terrorism is well-documented. The Israeli occupation of Palestinian territory is another case in point; Israel's engagement with international humanitarian law in the context the occupation and its own long-established state of emergency has culminated in the formulation of a concerted strategy aimed at amending the law in order to "to legitimise military policies which disregard the core IHL principles of distinction and proportionality". ${ }^{180}$ Palestinian activism based around international law has provoked an Israeli reaction which is drawing upon a 'lawfare' narrative in an attempt to recast international humanitarian law in its nineteenth-century colonial mould. The Israeli military's International Law Department is essentially advocating a full-circle return to the colonial paradigm of non-application to the

\footnotetext{
${ }^{178}$ Frederic Mégret, From 'Savages' to 'Unlawful Combatants: A Post-Colonial Look at International Humanitarian Law's 'Other', in International Law and its 'Others' (Anne Orford ed. 2006) 265, 270.

${ }^{179}$ See Anghie, supra note 12 , at 65-84.

${ }^{180}$ Michael Kearney, Lawfare, Legitimacy and Resistance: The Weak and the Law, 16 Palestine Yearbook of International Law 79, 104 (2010).
} 
indigenous population, arguing that the state's right to self-defence has been emasculated by extant principles of international humanitarian law. This is predicated on the idea that the protections and restrictions of Geneva Conventions are reasonable in situations of 'fair combat' between regular armies, but are ill-equipped to accommodate the emergency situation created by exceptional terrorist threats posed by non-state actors. ${ }^{181}$ In this sense we begin to see implications of the doctrine of emergency beyond human rights law.

\section{THe Rule of EMERgency: INTERnational Human Rights LAW's Colonial INHERITANCE}

While the UN-era human rights movement may have heralded progress in transcending international law's traditional focus on nation-states rather than individuals or communities, the state-centric structure of the discipline, and of the world order, was kept intact. The norms applied to crisis situations that constitute public emergencies can be seen as testament to this. In such circumstances, security considerations take precedence, often with the underlying motif of preservation of power, while respect for human rights obligations becomes more constraining and burdensome on a state. Accordingly, human rights law explicitly provides for exemptions, although it is precisely in such situations that rights are often most in need of protection. As described previously, these exemptions were nailed down in the midst of Britain's imperial emergencies abroad. The notion of emergency as developed in the British colonies was in essence a methodology of government by special powers, as opposed to government by consent. From the perspective of a foreign power faced with increasing resistance to its rule from subjugated populations, this represented the 'legal' alternative of suppression by legislation, which from a legitimacy point of view was favourable to the 'extralegal' approach of suppression by pure force. On the back of this experience, the doctrine of emergency was incorporated into the normative anatomy of international human rights law, and has become a coercive tool of choice for many states in their suppression of opposition and preservation of political stability:

In practice, there is an incurable tendency, particularly on the part of military dictatorships, to misuse the tool of emergency to maintain their own positions of power ... In many States, emergency and other states of exception have in some respects become a "normal" form of the exercise of State authority. ${ }^{182}$

This 'incurable tendency' would come as no surprise to students of British colonial history, which is replete with precedents of misuse of the tool of emergency to legitimise and

\footnotetext{
${ }^{181} / d$.

${ }^{182}$ Manfred Nowak, UN Covenant on Civil and Political Rights: Commentary $84\left(2^{\text {nd }}\right.$ ed. 2005) [emphasis in original].
} 
perpetuate Britain's position of power and control in the empire. In April 1918, for example, there was an extension of emergency powers of detention in Ireland "for a purely political purpose: to cripple the Irish Sinn Féin party". ${ }^{183}$ The same tactic was deployed in the African and Asian colonies until the last days of the empire, in a bid to protect British interests from the competing interests of the native 'other' - with whom Britain sought to maintain, in the Saidian sense, a relationship of power, of domination, of varying degrees of a complex hegemony. ${ }^{184}$ The invocation of an emergency was seen by the coloniser as an à la carte governance option to be selected when 'normal' political strategies met difficulties: "For the Colonial Office, opting for an emergency was based on the recognition that its conventional form of political management had not succeeded". ${ }^{185}$ The arguments used to justify the declaration of emergency were "often based on fiction"; in the cases of Malaya and British Guiana, for example, emergency measures were introduced in response to alleged communistinspired conspiracies to overthrow government, claims for which "[i]n reality, no evidence exists". ${ }^{186}$ On this basis, the emergencies are related less to actual extraordinary crises and more to the prevailing geopolitical landscape. The granting of a pivotal position to the concept of emergency within the international system for the protection of human rights reveals the inability of human rights law to fully shield itself from the corrupting vested interests of colonial powers that have plagued other elements of public international law.

The use of the state of emergency as a governmental tool of choice in contemporary politics, and the absorption of the exception into the norm is starkly illustrated by the fact that arguably the most draconian piece of British emergency legislation-the Terrorism Act of 2000-was enacted after the 1998 Good Friday Agreement heralded the diminution of overt conflict in Northern Ireland, and before the attacks of $11^{\text {th }}$ September 2001 and $7^{\text {th }}$ July 2005. The inferences to be drawn with respect to the extent of the truly 'emergency' nature of such an emergency regime are clear. The widely accepted discourse suggests a shift in paradigm brought about by the post-2001 transnational 'war against terrorism' and the onset of exceptionalism in the form of suspension or dilution of the normal rule of international law. We must question, however, whether an exceptional situation has in fact been created, or whether the invocation of extraordinary powers in the war against terrorism context is simply the successor of colonial traditions of emergency as a form of governance.

\footnotetext{
${ }^{183}$ Simpson, supra note 62 , at 643 .

${ }^{184}$ Terminology borrowed from Edward W. Said, Orientalism (1978).

${ }^{185}$ Füredi, supra note 54 , at 153 .

${ }^{186}$ /d., at $149-150$.
} 
The doctrine of emergency is symptomatic of the fatal flaws of international human rights law not only in its origins but also in its implementation. To the extent that it is used by governments as a political tool to circumvent legal obligations, the emergency derogations regime is prone to exploitation as a 'get-out clause', counter to the principle of good faith, and has effectively encouraged non-compliance. In so doing, it reinforces perceptions of the 'softness' of human rights law and international law more generally. Domestic and international judicial systems are also implicated. With the threat 'from within or without' remaining in colonial, neo-colonial and post-colonial situations, states are granted a virtually unfettered right to invoke a state of emergency by the judicial apparatus of both the state itself and the international human rights system.

The wide 'margin of appreciation' allowed to states to derogate from the ECHR under Article 15 was discussed in section V. On this, the language of the European Court of Human Rights is replicated word for word from its decisions on British derogations in relation to the 'Irish terrorist threat' in the 1970s to the 'Islamic terrorist threat' today. In its 2009 judgment in $A v$. UK, the Court recalls that:

it falls to each Contracting State, with its responsibility for "the life of [its] nation", to determine whether that life is threatened by a "public emergency" and, if so, how far it is necessary to go in attempting to overcome the emergency. By reason of their direct and continuous contact with the pressing needs of the moment, the national authorities are in principle better placed than the international judge to decide both on the presence of such an emergency and on the nature and scope of the derogations necessary to avert it. Accordingly, in this matter a wide margin of appreciation should be left to the national authorities. ${ }^{187}$

On this basis, the Court adjudged that although the measures implemented pursuant to Britain's 'war against terrorism' derogation were discriminatory and disproportionate, the declaration of emergency and the derogation itself were endorsed as legitimate ${ }^{188}$ In so doing, the decision upheld the ruling of the House of Lords, where eight of the nine justices accepted the claim of the Secretary of State for the Home Department that the question of the existence of an emergency is "pre-eminently one within the discretionary area of judgment reserved to the Secretary of State and his colleagues, exercising their judgment with the benefit of official advice, and to Parliament.." ${ }^{189}$ Citing "the unintrusive approach of the European Court to such a

\footnotetext{
${ }^{187} A$. and Others v. the United Kingdom, no. 3455/05, ECHR Grand Chamber judgment 19 February 2009, para. 173, replicating Ireland v. UK, supra note 166, para. 207.

${ }^{188}$ A v. UK, id., at para. 190.

${ }^{189} A(F C)$ and others (FC) (Appellants) v. Secretary of State for the Home Department [2004] UKHL 56, para. 25.
} 
question"190 with approval, the House of Lords had thus abstained from challenging the government's derogation from the European Convention. In his dissenting opinion, Lord Hoffman, while recognising that "the necessity of draconian powers in moments of national crisis is recognised in our constitutional history", ${ }^{191}$ argued that the threshold for such a necessity had not been met in this case. In a thought-provoking discussion of the meaning of a 'threat to the life of the nation', Lord Hoffman accepted that there was credible evidence of a threat of serious terrorist activity in Britain, but considered that it would not destroy the life of the nation, since the threat was not so fundamental as to imperil "our institutions of government or our existence as a civil community". ${ }^{192}$ He concluded that "[t]he real threat to the life of the nation, in the sense of a people living in accordance with its traditional laws and political values, comes not from terrorism but from laws such as these." ${ }^{193}$ Lord Hoffman was unanimously overruled by his House of Lords colleagues, and subsequently by the European Court of Human Rights.

The question of judicial supervision of derogation is perhaps most exposed by the cases of Brogan v. UK and Brannigan \& McBride v. UK. As noted earlier, in response to the European Court's decision in Brogan that its detention procedures were in violation of the Convention, the British government derogated under Article 15. Pursuant to the 'margin of appreciation' doctrine, the Court upheld the derogation in Brannigan \& McBride, without any substantive inquiry into the facts on the ground at the time. Had it done so and effectively supervised, the Court would have noted that the level of political violence had actually decreased during the period that elapsed between the two cases, and on that basis that the derogation was arguably not justified.

\section{Cause and Effect?: Colonial to Post-Colonial Emergencies}

The domino effect of the emergency legislative code developed by Britain as part of its governance of Ireland in the nineteenth century on the Defence of the Realm Acts, the Defence of India Act, the Palestine Defence (Emergency) Regulations, and so on, was discussed in section II. The incorporation of the doctrine of emergency into international human rights law can be seen as an extension of that momentum. Beyond that, it may also be argued that this effective approval of emergency measures by major international human rights conventions has had an influence on the propensity of states to avail of emergency as a smokescreen for

\footnotetext{
${ }^{190} / d$. , at para. 29.

${ }^{191} / d$., at para. 89.

${ }^{192} / d$., at para. 96.

${ }^{193}$ /d., at para. 97.
} 
repression. Had the British government not had the option of submitting a derogation to the ECHR to circumvent the European Court of Human Rights' decision in Brogan in 1988, would it have been inclined to persevere with its detention policies in the north of Ireland? In the absence of the right to derogate, would it have even introduced those policies in the first place, under its original 1957 derogation? Would Turkey have felt comfortable enacting measures contravening almost all of the non-derogable rights enumerated in the $\mathrm{ECHR}^{194}$ without the legitimising blanket of derogation to wrap itself in?

The influence of the doctrine of emergency in the states that acquired independence from colonial rule also bears consideration. For such states, upon formal independence, sovereignty over their own affairs was "the legal epitome of the fact that they are masters in their own house". ${ }^{195}$ In Ireland, the legacy of Britain's emergency doctrine lived on in emergency measures introduced in the newly-independent Free State in the face of civil war and internal divisions. ${ }^{196}$ Subsequently, the Emergency Powers Act of 1939, enacted to deal with the "national emergency affecting the vital interests of the State" brought about by the Second World War, was kept on the statute books long after 'The Emergency' had concluded, and was used by the government as the basis to adopt broad powers in response to prevailing IRA campaigns, and to derogate from the ECHR.

Post-colonial regimes from the Irish Free State to Egypt to Sri Lanka came from the colonial experience to appreciate the value of emergency measures and techniques as political weapons for the containment and suppression of opposition. In Asia, the doctrine of emergency helped to legitimise "repressive measures and laws such as the Internal Security Act which is a standard tool in the coercive apparatuses of states such as ... India, Pakistan, Sri Lanka, Malaysia, Indonesia, and Singapore." ${ }^{197}$ Continuous long-term states of emergency have been maintained in Arab states such as Algeria, Egypt, and Syria, where leaders "have learnt the lessons taught by their former colonial masters - that international law need not be a hindrance to action if one has the power to proceed". ${ }^{198}$ The concrete legacy of British emergency measures is also very much in evidence in Israel, at once a post-colonial and colonial state that has been in a self-declared state of emergency since 1948. Israel continues to use the Palestine Defence (Emergency) Regulations of 1945-the very same emergency laws imposed

\footnotetext{
${ }^{194}$ See, for example, Letter from the Permanent Representation of Turkey, dated 6 August 1990, registered at the SecretariatGeneral of the Council of Europe on 7 August 1990, providing notification of derogation from Articles 5, 6, 8, 10, 11 and 13 .

${ }^{195}$ Georges M. Abi-Saab, The Newly Independent States and the Rules of International Law: An Outline, 8 Howard L. J. 95, 103 (1962).

${ }^{196}$ For a full overview, see Seosamh ÓLongaigh, Emergency Law in Independent Ireland, 1922-1948 (2006).

${ }^{197}$ Rajagopal, supra note 7, at 177.

${ }^{198}$ Jean Allain, International Law in the Middle East: Closer to Power than Justice 196 (2004).
} 
by the British and used against Jewish activists in mandate Palestine before being denounced in the Knesset following the creation of Israel as "Nazi, tyrannical, and unethical"199-as the basis for repressive 'emergency' policies against Palestinians.

In this sense, the crucial point is that by virtue of human rights law embedding the concept of emergency in its instruments, measures that were originally often conceived of as sui generis responses in specific historical contexts have become normalised not just in our legal documents but in our thinking. According to a 1997 UN Special Rapporteur report notes that "between January 1985 and May 1997, some 100 States or territories - in other words, over half the Member States of the United Nations - have at some point been de jure or de facto under a state of emergency." ${ }^{200}$ In this regard, it is clear that the resort to extraordinary powers is by no means a novel phenomenon that has arisen in a post-2001 exceptional situation. Rather, it has been prevalent before and since the channelling of emergency powers into international law; a constant presence through shifting contextual sands of Third World liberation movements and decolonisation, ideological Cold War totalitarianism, military dictatorships, separatist conflicts, economic shock policies and national security doctrines.

\section{Theorising the State of EXCEPtion: Implications of the Colonial FramewORK}

In 1865, an uprising of Jamaican peasants in Morant Bay, was put down by British colonial troops acting pursuant to a declaration of martial law. While the rebellion itself was small and easily contained, its suppression was defined by a period of prolonged and brutal statesanctioned violence against the native population, involving collective punitive reprisals and an excessive and disproportionate use of force. Intense debate in English legal circles ensued over the legality and legitimacy of the actions of the troops, prompting Rande Kostal to note the centrality of law in the world-view of the English political class of the time. ${ }^{201} \mathrm{~A}$ simultaneous commitment to empire and the rule of law presents itself. The case of Jamaica, like many other colonial situations before and after it, personifies the colonial 'usurper' seeking to transform his usurpation into legitimacy. The English governing class purported to balance its love of power with a love of law, with both the colonial authorities in Jamaica and the imperial authorities in London genuinely preoccupied with the legality of their actions. The 'Jamaica affair' thus

\footnotetext{
${ }^{199}$ Statement of Menachem Begin, then leader of the opposition, Knesset Records, Volume 9 (12 May 1951), p. 1807. Quoted in B'Tselem, Detained Without Trial: Administrative Detention in the Occupied Territories Since the Beginning of the Intifada 24 (1992).

${ }^{200}$ UN Commission on Human Rights, Report of Leandro Despouy, Special Rapporteur of the UN Sub-Commission on Prevention of Discrimination and Protection of Minorities, UN Doc. E/CN.4/Sub.2/1997/19, 23 June 1997, at para. 180.

${ }^{201}$ See generally Kostal, supra note 38 .
} 
prompted significant questions over the scope and substance of martial law, and cruciallynotwithstanding the centrality of law to the debates-over whether it was conceivable that in a British-controlled territory certain British policies and practices could be conducted outside the ambit of the rule of law:

[M]artial law was about taking extreme and extra-legal measures to rescue the basis of all law, the state. Could these measures be subject to law? Was 'martial law' law, or was martial law a state of non-law, a state of official and pragmatic lawlessness? This order of inquiry, at bottom philosophical in nature, was beyond the ken of most lawyers, certainly of most politicians and imperial administrators. ${ }^{202}$

Lawyers, political theorists and philosophers have long since been grappling with these challenging questions, and continue to do so, both in respect of martial law specifically and the state of exception more broadly. Although martial law is less common in its usage today, particularly in liberal democracies, "it has clear analogues in declarations of states of emergency, in delegations from the legislature to the executive of virtually unlimited authority to deal with threats to national security, and in assertions of inherent jurisdiction by the executive to respond as it sees fit to such threats. ${ }^{203}$ Thus, what David Dyzenhaus dubs "the puzzle of martial law" - the question of whether martial law is really law- "has obvious echoes in post-9/11 debates". ${ }^{204}$ At this juncture, then, it is useful to recall the three alternative theories of martial law discussed earlier. ${ }^{205}$ The question as to whether martial law is in fact law is answered in the negative by the approach that posits it as no more than the will of the General who commands the army, acting, for all intents and purposes, beyond the pale of legal constraint. Conversely, the two competing approaches both posit that martial law does operate within the rule of law, in different forms: Dicey's theory holds that it emanates from the common law right to use force in self-defence and functions autonomously within the law; while the state of siege-influenced approach suggests military rule temporarily replacing or augmenting civilian rule during crises, but remaining nonetheless subject to certain constitutional limitations.

These three models are effectively mirrored in the more contemporary debates on states of exception. The fundamental question remains the same: whether the exception is situated within the rule of law, or in a lawless space beyond. Scholarship on the matter is divided

\footnotetext{
${ }^{202} / d_{\text {. }}$, at 16.

${ }^{203}$ Dyzenhaus, supra note 43 , at 2.

${ }^{204} / d_{\text {., at } 3 .}$

${ }^{205}$ See Section II.i, supra.
} 
between those who seek to include the state of exception within the juridical order, and those who consider it something external - an essentially political, or in any case 'extra-juridical' phenomenon that manifests itself in fact, rather than in law (although it may have consequences in the sphere of law). Within the first school of thought there are those who see exceptional measures as an integral and autonomous part of law (similar to Dicey's engagement with martial law); while others consider the exception as the state's subjective right to invoke when necessary. ${ }^{206}$

The debate on the theory of exception strikes to the very core of the state in terms of how it is constituted and where power is ultimately vested. The idea that a state of exception-under which law is suspended-may be itself initiated by law is a somewhat paradoxical situation, inherently difficult to reconcile. Carl Schmitt, for one, was of the opinion that it is irreconcilable. He deals with the dilemma by locating the source of the contradiction outside the constitutional order, implying that the political authority of the state is not at root constituted by law. The sovereign is he who decides on the exception, and is unconstrained by law both (i) in making such a decision, and (ii) in responding to the exception. ${ }^{207}$ At the same, the political decision is nonetheless bound to the legal order: "like every other order, the legal order rests on a decision and not on a norm" ${ }^{208}$ As such, for Schmitt, although the state of exception is an act of political authority through which the relationship between state and law is thrown out of kilter (where "the state continues to exist, while law recedes"209), the decision and enforcement of the state of exception retain the force of law: "authority proves that to produce law it need not be based on law". ${ }^{210}$ This approach has parallels to the idea of martial law as being no more in its foundation than the will of the General who commands the army, but yet having the full force of law in its implementation.

Dicey, for his part, espouses the view that the state is constituted absolutely by law. As such, the sovereign is fully subject to the rule of law and has no authority to use law to suspend law. According to this approach, measures to be taken during an emergency are contained within the law. This echoes what Oren Gross describes as the 'business as usual' model of response to an emergency, according to which:

\footnotetext{
${ }^{206}$ See Agamben, supra note 15, at 22-23.

${ }^{207}$ Carl Schmitt, Political Theology: Four Chapters on the Concept of Sovereignty (George Schwab trans., University of Chicago Press 1985) (1922).

${ }^{208} / d_{\text {., at } 10 .}$

${ }^{209} / d_{\text {, }}$ at 12 .

${ }^{210} / d$.
} 
[A] state of emergency does not justify a deviation from the "normal" legal system. No special "emergency" powers are introduced either on an ad hoc or permanent basis. The ordinary legal system already provides the necessary answers to any crisis without the legislative or executive assertion of new or additional governmental powers. The occurrence of any particular emergency cannot excuse or justify a suspension, in whole or in part, of any existing piece of the ordinary legal system. ${ }^{211}$

This model is predicated on a rejection of the idea that a tension exists between a nation's security on one hand, and individual liberties and the rule of law on the other. Emergencies and crises, when they do arrive, do not affect the constitutional order, of which a unitary vision is offered. The obvious criticism of such a hypothesis is that it is naïve or even hypocritical. History is testament to the fact that when faced with an emergency situation, government will take whatever measures it deems necessary to abate the crisis. It is precisely for this reason that Schmitt regarded this kind of approach as a liberal fallacy, blind to the reality that, when it comes to it, political authority will not be constrained by law. In advancing his own version of the 'business as usual' paradigm in the common law context, Dicey's arguments also raise questions and contradictions. While generally adhering to a categorical impenetrability of the rule of law, he does however sporadically acknowledge that a post-emergency Act of Indemnity can serve to protect those who have broken the law in the discharge of a political duty, essentially legalising illegality. ${ }^{212}$ In this sense, Dicey's approach is echoed by the model proposed by Gross as an alternative to the traditional approaches to emergency powers, which he labels the 'extra-legal measures' approach. Under this proposed model, public officials may respond 'extra-legally' ${ }^{213}$ to an exceptional threat. This "entails going outside the legal order, at times even violating otherwise accepted constitutional principles", ${ }^{214}$ something that is acceptable once the officials openly acknowledge and disclose the nature of their actions, and submit to the authority of ex post judgment of the necessity of those actions, to be either punished or exempted. This differs from the conception of a void beyond law in that while the actions may be 'extra-legal', law still plays a central role in their subsequent ratification or invalidation. This model also does not affect the substance of the applicable law, but rather provides potential immunity from prosecution for breaches of that law. Gross goes as far as to invoke the 'extra-legal measures' thesis to allow for retrospective justification of torture. ${ }^{215}$ The

\footnotetext{
${ }^{211}$ Oren Gross, Chaos and Rules: Should Responses to Violent Crises Always be Constitutional?, 112 Yale L. J. 1011, 1043-44.

${ }^{212}$ Dicey, supra note 20, at 554 .

${ }^{213}$ Gross' choice of terminology is somewhat misleading. By characterising acts as 'extra-legal', he implies them to be outside the scope of what the law governs, when in reality such acts will generally not be beyond law, but rather illegal.

${ }^{214}$ Gross, supra note 211 , at 1097. Gross does therefore acknowledge, albeit tacitly, that 'extra-legal' measures may in fact be simply illegal.

${ }^{215}$ See Oren Gross, The Prohibition on Torture and the Limits of the Law, in Torture 229-250 (Sanford Levinson, ed. 2004).
} 
fundamental flaw inherent in this paradigm is that public officials, acting 'extra-legally' on behalf of their government invariably against alien or perceived subversive individuals or groups, will have a well-grounded expectation of ultimate indemnity for their actions. This way, repressive, illegal measures are liable to seep into common and accepted usage during situations of real or perceived emergency.

The second of the two traditional models of response to exceptional threats that Gross had identified is that of 'accommodation', which allows "a certain degree of accommodation for the pressures exerted on the state in times of emergency, while, at the same time, maintaining normal legal principles and rules as much as possible". ${ }^{216}$ Here, the power to declare a state of emergency and to suspend law to the degree necessary is an exceptional one, but one which is rooted in the constitution or its equivalent. When this power is invoked by the sovereign, therefore, it is subject to constitutional restraints on its exercise. The 'state of siege' style interpretation of martial law can be construed as a model of accommodation, and it is this construction that perhaps best illuminates the imposition of martial law as an exceptional measure in the British empire to accommodate the use of force in suppressing anti-colonial sentiment. Similarly, the system of emergency legislation introduced in nineteenth-century Ireland and further throughout the empire in the twentieth century is most accurately described as a model of 'accommodation'. ${ }^{217}$ The 'normal' legal system in England was insufficient to accommodate British imperial ambitions abroad, and thus flexibility was required in retaining the ability to legislate for exceptional threats. As we have seen, such flexibility was exploited during the course of the colonial project as a technique of domination and in order to mask widespread dispossession and exploitation in a shroud of legitimacy.

The influence of the British colonial emergency paradigm on the derogations regime in international human rights law has also been suggested herein. This regime itself can likewise be diagnosed as a model of accommodation, whereby parts of the given human rights convention are suspended, but not without constraints, while at the same time normal legal principles and rules are retained as much as possible. From a Schmittian perspective, the accommodation model is flawed as the legal constraints are ultimately illusory. As such it is liable to lead to the absorption of the exception into the norm, rendering the executive free to act with full discretion while simultaneously claiming deference to the rule of law.

Similarly, the suggestion that the partial or total suspension of law can be inscribed within the legal order itself is what prompts Georgio Agamben to explicate the state of exception as "the opening of a fictitious lacuna in the order for the purpose of safeguarding the existence of the

\footnotetext{
${ }^{216}$ Gross, supra note 211 , at 1058 .

${ }^{217}$ Gross explicitly identifies special emergency legislation as a model of accommodation. See id., at 1065 .
} 
norm and its applicability to the normal situation" ${ }^{218}$ Agamben sees the norm-exception divide within law as essentially artificial and, effectively arrives at a conclusion that goes even beyond Schmitt in understanding the state of exception as "a space devoid of law, a zone of anomie in which all legal determinations ... are deactivated". ${ }^{219}$

The predicament that this conclusion presents for proponents of the rule of law is clear: to accept that the state of exception is situated in a space beyond law is to concede that law is powerless to regulate emergencies. At the same time, however, to facilitate the emergency by the creation of an exceptional legal regime implicates the law insofar as it provides legitimacy to whatever executive action is taken. To overcome this predicament, it is necessary to "respond through law to emergencies without creating an exceptional legal regime-alongside the ordinary one-that will permit government to claim that it is acting according to law when it in effect has a free hand and will, the longer the exceptional regime lasts, create the problem of seepage of government outside of the rule of law into the ordinary legal order". ${ }^{220}$ Toward this end, Dyzenhaus argues that Dicey's denial that the English constitution made any place for martial law in the sense of the French state of siege provides the foundational framework for such a response. Such an argument, however, overlooks Dicey's express proviso that this denial did not extend to the empire. The colonial paradigm of states of emergency may indeed throw a spanner in the works. For the exceptional legal regime that was applied in the colony and deviated from the ordinary one in the metropole-the very prototype which Dyzenhaus seeks to avoid-is the model that has influenced modern emergency measures, more so than common law responses that applied to English citizens.

At root here is the use of the state of emergency to legitimise colonial 'usurpation' throughout the empire, and as a technique of control over the native 'other'. The doctrine of emergency is ostensibly tied to that of non-discrimination, but it is difficult to envisage situations in practice where it would be invoked without certain groups being targeted, particularly in the context of the prevailing emergency paradigm of hegemonic control or repression. Gross describes "the greater willingness to confer emergency powers on the government when the 'other' is welldefined and clearly separable from the members of the community. The clearer the distinction between 'us' and 'them' and the greater the threat 'they' pose to 'us,' the greater in scope become the powers assumed by government". ${ }^{221}$

\footnotetext{
${ }^{218}$ Agamben, supra note 15 , at 31.

${ }^{219} / d$., at 50 .

${ }^{220}$ David Dyzenhaus, Schmitt v. Dicey: Are States of Emergency Inside or Outside the Legal Order?, 27:5 Cardozo L. Rev. 2005, 2030 (2006).

${ }^{221}$ Gross, supra note 211 , at 1037 .
} 
Experience suggests that expectations of the principle of non-discrimination operating as a selfimposed restraint on the state of emergency are somewhat idealistic. Among the reasons proffered for the eventual implosion of the Roman dictatorship is the corruption of the institution by its use as a coercive tool against the plebeians in the Roman class war. ${ }^{222}$ More contemporaneously, in A. v. UK, the European Court of Human Rights found that the British 'war against terrorism' emergency measures in question "were disproportionate in that they discriminated unjustifiably between nationals and non-nationals". ${ }^{223}$ In appraising the postSeptember $11^{\text {th }}$ emergency measures in the United States, Agamben asserts that the military order regime of indefinite detention of noncitizens suspected of endangering US national security is entirely removed from the law and from judicial oversight. Insofar as it "erases any legal status of the individual, thus producing a legally unnamable and unclassifiable being", it is comparable only to "the legal situation of the Jews in the Nazi Lager [camps], who, along with their citizenship, had lost every legal identity". ${ }^{224}$ But like much of the contemporary scholarship on the state of exception, Agamben's focus does not envelop past or lingering colonial situations. Agamben's 'bare life' thesis has, however, much resonance in the colonial context. The colonised native, the epitome of 'otherness', was denied status in the legal system of the coloniser, ruled by law, but not entitled to the rule of law protections afforded to, in the British case, subjects of the Crown by the common law of England. In a similar vein, Palestinians in the occupied West Bank and Gaza Strip have no claim to the Israeli constitutional protections that their Jewish-Israeli neighbours in those territories benefit from.

Appraising the use of the doctrine of emergency through the lens of its colonial underpinnings, therefore, brings additional perspectives to the state of exception discourse, and the debate as to whether the state of exception is something grounded in law, or exists in a zone of anomie beyond law. Faith in the notions of the state of emergency and the right to derogate as integral to the rule of law is based on the principles of full judicial oversight, temporality, and the validity of the norm-exception divide. In the colonial context and in its continuing legacy, these principles have been erased or at best severely blurred. While the fact that emergency derogations from human rights obligations may be subjected to judicial scrutiny is held up as evidence of the overarching primacy of the rule of law, in reality the degree of judicial supervision is found wanting. A review of the jurisprudence of the House of Lords and the European Court of Human Rights demonstrates that that even where a Court will rule that special measures implemented under an emergency are excessive, it will invariably refrain from questioning the state's decision to declare the emergency in the first instance. Temporal limitations on a state of emergency in practice were conspicuous by their absence during

\footnotetext{
${ }^{222}$ Reinach, supra note 16 , at 16 .

${ }^{223}$ A v. UK, supra note 187 , para. 190.

${ }^{224}$ Agamben, supra note 15 , at 3-4.
} 
Britain's entrenched colonial emergencies; a reality which has only proliferated through the 'permanent' emergencies that we see in the 'post-colonial' age. The conceptual and spatial aspects of the normalcy-emergency divide, tied to the metropole-colony distinction, have been distorted by the evolution in forms of imperialism and the rise of transnational 'wars' against amorphous terrorist threats. Illuminating the colonial shadows from which the doctrine of emergency emerged, therefore, reveals the state of emergency as a vehicle for law's violence, grounded in the dynamics of domination. 